Is Optimization an Opportunity? An Assessment of the Impact of Class Size and School Size on the Performance of Ukrainian Secondary Schools

\title{
Tom Coupé
}

Kyiv School of Economics and Kyiv Economics Institute

Anna Olefir

World Bank

Juan Diego Alonso

World Bank 


\title{
Is Optimization an Opportunity? \\ An Assessment of the Impact of Class Size and School Size on the Performance of Ukrainian Secondary Schools
}

\author{
Tom Coupé \\ Anna Olefir \\ Juan Diego Alonso
}

June 2, 2011

Human Development Sector Unit

Europe and Central Asia Region

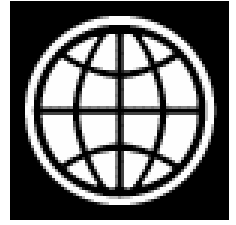

Document of the World Bank 


\begin{abstract}
:
Using a rich dataset of almost the entire population of Ukrainian secondary schools, the authors estimate the effect of school size and class size on the performance of secondary schools on Ukraine's Independent External Test. They find that larger schools tend to have somewhat better performance, both in terms of test scores and in terms of test participation. The size of this effect is relatively small, however, especially in rural areas for which the estimates are likely to be more clean estimates. Class size is found to be insignificant in most specifications and, if significant, of negligible size.
\end{abstract}




\section{Introduction}

The substantial positive returns to education for both individuals (e.g. Psacharopoulos and Patrinos, 2004) and countries (e.g. Barro and Lee, 2010) are a fairly established fact in the literature of the economics of education. It comes as no surprise,then, that policy makers and academicians are so interested in understanding the factors that can influence the quantity and quality of education.

While the academic literature on these factors is vast, most of it focuses on developed countries, and while there is some literature on developing countries, only recently have studies using data from countries in Eastern Europe and the Former Soviet Union (henceforth, transition countries) started to appear. The recent surge in this literature can be explained by the fact that performance measures for these countries have become available, both through the participation of these countries in international assessments of student learning like the Organisation for Economic Cooperation and Development (OECD)'s Programme for International Assessment (PISA), the Trends in International Mathematics and Science Survey (TIMSS) and Progress in International Reading Literacy Survey (PIRLS), and through the introduction of centralized nation-wide assessments in several transition countries.

In terms of the development of their educational systems, transition countries may be considered to lie somewhere between developed and developing ones. Transition countries typically have had mandatory basic education and enjoy very high levels of school attendance. As a result, so the issue is not how to get children to attend school, as it is in a big part of the developing world. Instead, transition countries face the challenge of how to modernize and reform their educational system so as to provide quality education at an affordable price.

One possible opportunity to realize such quality enhancing reforms might come from taking advantage of the so-called "demographic dividend", i.e. the sizeable demographic changes that took place in most of the transition countries, especially in the last 20 years. In fact, after the fall of the Soviet Union, transition countries have faced an unprecedented demographic shock, with increasing mortality and emigration, but also with a serious drop in fertility. This negative shock 
to fertility has translated in an increasingly smaller number of school-aged children, considerably reducing school size and class size over time (Berryman, 2000). In addition, given that this drop in children of school age did not go together with a decline of the number of schools, teachers or classes, student-teacher ratios and the size of schools and classes has decreased substantially. As a consequence, transition countries are now in the situation where they have a disproportionately large number of schools, teachers and classes. And this oversized system does not appear to have led to an improvement in the quality of education.

Many transition governments are now facing the question of what to do with these oversized systems, often characterized by a multitude of very small schools and very small classes within schools. From a budgetary point of view, many governments would like to merge small schools, as the budgetary burden of one big school with many students is typically smaller than the budgetary burden of having a network of many small schools with few students each. Similarly, consolidating classes within schools appears as an attractive option to generate some savings that could then, at least partially, be reinvested in increasing the skills and performance of the remaining schools, classes and teachers, presumably leading to quality improvements in the educational system.

In several transition countries, this consolidation movement is already ongoing ${ }^{1}$. Kuddo (2009) describes the process in Armenia, Kallai and Manui (2004) in Romania, Herrmann (2005) in Hungary, the World Bank (2010) in Bulgaria, McGuinness et al (2001) in Estonia, Hazans (2010) in Latvia, and Berdashkevich and Vlasov (2010) in Russia.

The Government of Ukraine is progressively coming to the understanding that school network optimization should be a key issue on any education reform agenda in the coming years in Ukraine $^{2}$. Optimization of the school network is also among the key steps for reforms in the

\footnotetext{
1 Throughout this document, the terms "optimization", "consolidation" and "rationalization" are used interchangeably. In all cases, they refer to the territorial reorganization of the school network in a way that could better use the available resources in the system maximizing the installed capacity of current institutions. Since the system is overly underutilized, the optimization/consolidation/rationalization of the school network would entail the closing of classes and schools and the merging/reallocation of students in those classes and schools to the best available option within the nearby institution. This may also require some degree of transportation of students.

${ }^{2}$ The dialogue on the optimization of the school network in the framework of Bank-supported 'Equal Access to Quality Education' lending project started to materialize in 2007 when the line Ministry defined the pilot oblasts (Order №571 of August 16, 2007). Since then the project lead to several successful school closures in selected six pilot rural districts - seven schools were closed and eight schools stopped functioning without obtaining official status of closed institutions. Of course, optimization activities were limited to a few pilots, thus its impact in the
} 
education sector according to the Presidential Economic Reforms Program for 2010-2014 'Prosperous society, competitive economy, effective government'. Also the 'launch of optimization' of the school network is envisaged by the Ukraine's Budget Declaration for 2011 which was approved on April 19, 2010. Schoolsare planned to be closed if they:

- have less than 10 students and only offer grades 1-4 (level I schools);

- have less than 40 students and only offer grades 1-9 (level I-II schools);

- haveless than 100 students and offer all grades (1-11/12, level I-III schools) ${ }^{4}$.

School size is thus used as the key decision criterion to close schools. Given that pupils of closed schools will be reallocated to other schools, the remaining schools will see an increase in size and most likely will have the size of their classes increase. Also the Budget Declaration 2011 set to revise the school norms that influence the amount and type of staff to be hired.

In this paper, we attempt to study what the impact of school size and class size are on the performance of schools in Ukraine, using data on educational performance from Ukraine's Independent External Test and data on educational inputs from the Ukrainian Ministry of Education, Youth, Sports and Science. The paper is intended as a key input in the discussions around the optimization or consolidation of the network of schools in Ukraine that has been ongoing for some time now.

In Section II,we first review the academic literature on the determinants of educational performance with a particular emphasis on the evidence that links class size and school size to educational outcomes. Section III portrays a picture of Ukraine's educational system, again with an emphasis on size of schools and classes. Section IV provides a detailed description of the data used in this study and how the database was assembled. It is the core of the paper andpresents our estimates of class size and school size effects within the 'educational production functions' of

overall education system is negligible. Nevertheless, close to its end the project supported a number of important activities that created basic conditions for further consolidation in pilots in the near future through necessary investments like school buses, school labs and textbooks for hub schools, training of school directors and teachers and stimulated optimization discussions and work in non-pilots. While such activities created conditions for modernization of the education, the larger, more comprehensive reform and completion of the consolidation exercise remains to be implemented.

${ }^{3}$ However, there are still signs of a push-back from the Government's original initiative due to fierce local opposition to school closures.

${ }^{4}$ The system was undergoing transformation to 12-years of schooling (with experiment already in place in some schools) but in mid-2010 the decision was taken to return to the system of 11-years of full secondary education. 
Ukraine. Section V, finally,summarizes the main messages and policy conclusions from this empirical study.

\section{Literature Review}

In this section, we start by providing a short overview of the findings of the literature on school size and class size effects for both developed and developing countries. Then we zoom in on transition countries, first reviewing those cross-country studies that include transition countries, and after that focusing on studies that use data for specific transition countries.

II.1 The evidence from developed and developing countries

There are several reviews of the literature on the determinants of educational performance, both internationally (Hanushek\&Woessman, 2010) and focusing on developing countries (Glewwe (2002) and Glewwe\&Kremer (2005)) $)^{5}$. Some of these reviews have focused specifically on the effects of school size and class size. Ahn and Brewer (2009, p.426) for example summarize the channels through which class size can matter as follows:

- teachers report less stress and dissatisfaction with working conditions

- teachers may have more time for individual attention

- student motivation may increase leading to better learning

- behavioral and class management issues are less frequent

- achievement scores in grades K-3 improves for students exposed to classes of 17 or less

- achievement gains increase with longer exposure to small classes in grades K-3

- achievement gains are seen for historically underserved and disadvantaged student populations in grades K-3

Reviewing studies for OECD countries, Vignoles et al (2000) conclude that:

\footnotetext{
${ }^{5}$ Two general messages emerge clearly from these reviews. The first one is that methodologically, it is very hard to obtain pure unbiased estimates of the impact of specific determinants on education quality; most studies, including ours, are plagued by issues like selection effects and endogeneity, and experimental studies are rare. The second is that the vast amount of studies on inputs gives a mixed picture, with many studies showing an impact but also many studies finding insignificant effects.
} 
1. The impact of class size is mostly insignificant, and where it is significant, the effect is too small to justify expenditures for class size reduction.

2. Interaction effects of class size with other factors (students' abilities, school type, teachers' actions) have been found to be significant suggesting that class size can affect specific groups of students.

In line with this, Lazear (1999) shows that smaller classes substitute for better discipline - more specific, students of Catholic schools have better school achievements in larger classes. Babcock and Betts (2009) demonstrate that low-effort students lose more from class size increases as they require more attention of their teachers. Wößmann and West (2002), using a sample of 18 developed countries, find that for most countries class size has an insignificant impact on student performance. However, in Iceland and Greece reduced class size does seem to positively influence TiMSS scores, which they explain by the lower quality of teachers in these countries teachers there have relatively lower salaries and qualifications.

The arguments in favor of school sizeare similar to those in favor of small classes - smaller schools are more 'personalized', can have more 'adaptive' pedagogy and will involve parents more. On the other hand, bigger schools could exploit economies of scale and hence provide better quality for a given level of inputs.

Garrett et al (2004) provide an extensive review of school size literature based on the United States (US) and the United Kingdom (UK) data. Their review suggests an inverted-U relation between school size and student exam scores, though larger schools are typically found to be more cost-efficient. They also point out that teacher and student perceptions of school climate decline $^{6}$ and some kinds of violent behavior ${ }^{7}$ may increase with school size.

More recently, focusing on the US and Canada, Leithwood and Jantzi (2009) conclude that smaller schools mostly benefit younger students and those with a disadvantaged social and economic background. They state that "elementary schools with large proportions of such students should be limited in size to not more than about 300 students; those serving economically and socially heterogeneous or relatively advantaged students should be limited in

\footnotetext{
${ }_{7}^{6}$ E.g. parental involvement into school matters decline with school size - Walsh (2010).

${ }^{7}$ For example, Leung and Ferris (2008) use Canadian data to show that that a student attending a school with more than 2000 students is 22 percent more likely to engage in an act of serious violence.
} 
size to about 500 students. Secondary schools serving exclusively or largely diverse and/or disadvantaged students should be limited in size to about 600 students or fewer, while those secondary schools serving economically and socially heterogeneous or relatively advantaged students should be limited in size to about 1,000 students (p.1)."

Consistent with this, Berry and West (2005), using US data, find a negative effect on future earnings of both a higher school size and a higher pupil-teacher ratio.

The abovementioned studies focus on the estimation of educational production functions where educational performance is the variable to be explained. Other studies estimate educational cost functions, in which educational performance is used as an explanatory variable. Studies that use this approach tend to find that existing schools are smaller than optimal (Kenny 1982, Smet 2001, Stiefelet al. 2009). But also among these studies there is no clear consensus on the optimal school size. For example, a review of US-based studies by Andrews et al. (2002) suggests that 500-600 students may be an optimal size, although there is no consistent evidence of either increasing or decreasing returns to scale.As far as developing countries are concerned, Hanusek (1995) summarizes the literature on the effect of class size in developing countries as follows: "The evidence provides no support for policies to reduce class size. Of the thirty studies investigating teacher-pupil ratios, only eight find statistically significant results supporting smaller classes; an equal number are significant but have the opposite sign; and almost half are statistically insignificant. These findings qualitatively duplicate those in the U.S. studies, but are particularly interesting here. Class sizes in the developing-country studies are considerably more varied than those in the U.S. studies and thus pertain to a wider set of environments, providing even stronger evidence that the enthusiasm for policies to reduce class size is misplaced (p.231)". More recent studies confirm the mixed evidence: Urquiola (2006) finds a negative effect of class size on student performance in Bolivia, while NiazAsadullah (2005) finds the opposite for Bangladesh. And in a recent review, Hanusek and Woessman (2007, p.66) conclude that "The lack of substantial resource effects in general, and class-size effects in particular, has been found across the developing world, including Africa (...), Latin America (...) and East Asia (...)". There are only few studies that focus on school size in developing countries.Duflo et al (2009) included school size as one of the explanatory variables into an educational production function for Kenyan schools, and find in some specifications a small negative effect. Liu et al (2009) 
estimate the effect of a primary school merger policy conducted in rural China. Within this policy about 25,000 rural primary schools a year were closed between 2001 and 2005. They conclude that mergers were beneficial forthe school performance ofolder students $\left(4^{\text {th }}\right.$ grade) and worsened the results of younger $\left(1^{\text {st }}\right.$ grade $)$ students.

One study studies the effect of school size on student performance using TiMMS data for both developed and developing countries: Schütz (2006) finds significant size effects for 11 out of 51 countries, 8 out of these 11 are developing countries. Most of these significant effects are positive, suggesting that, if there is a relationship between size and performance, bigger schools appear to be typically better.

\section{2 The evidence from transition countries ${ }^{8}$}

The literature on schools in transition countries is much less developed than the literature on either schools in developed countries or schools in developing countries. This paper is indeed the first that tries to summarize the existing literature on schools in transition countries. We divide what follows into two parts: we first focus on the cross-country studies that include transition countries. Next, we focus on single-country studies.

\section{a. Cross-country studies}

There is a number of studies that do include data from transition countries, even though they do not focus on transition countries or have specific conclusions based on the estimations they obtain for transition countries.

Hanushek and Luque (2002) and Hanushek (2003), reviewing a hundred production function estimates covering 37 developed and developing countries ${ }^{9}$, state that there is no consistent evidence that more school resources and better teacher quality lead to better test results, since in the majority of studies these variables are found to be insignificant. Despite this, studies for ${ }^{8}$ Table A1 and A2 in the appendix summarize the empirical findings of education-relevant factors in transition
countries, and in developed and developing countries.

\footnotetext{
${ }^{9}$ Among them eight transition economies: Hungary, Latvia, Lithuania, Poland, Slovak Republic, Czech Republic, Romania and the Russian Federation.
} 
developing countries find some positive relationship in a greater share of cases ${ }^{10}$ (possibly because the initial level of education spending matters). Class size is most often found to be insignificant, but for transition countries, if significant typically positive. These authors recommend that rather than focusing on inputs, the focus should shift to other policies, including giving right incentives for teachers, and increasing school competition.

The importance of incentives is confirmed by a study of Woessman (2003) who estimated an education production function based on student-level data for 260000 students from 39 developed and developing countries ${ }^{11}$. He finds that school autonomy (teacher incentives) and centrally controlled examinations (student incentives) do positively and significantly influence educational performance. He does not consider the school size variable, however, while higher class size has a positive effect on education outcomes.

There is one cross country study that focuses on transition countries. Ammermuller et al (2003) estimate an education production function for seven Eastern European countries (excluding Russia) using the TiMMS 2003 wave. Their study finds that class size has a positive influence on test scores, only if one does not control for selection effects. Once selection effects are controlled for the coefficient of class size becomes insignificant. Other included school characteristics, such as shortage of materials and measures of teacher and school autonomy were also found to be insignificant in most cases.

\section{b. Single-country studies ${ }^{12}$}

Single transition countries studies so far focus on the Central European countries with, as far as we could find, no evidence being available about countries which belong to the Commonwealth of Independent States (CIS).

Three studies use Polish data to study the determinants of educational performance.Herczynski and Herbst (2005) find a small positive effect of class size. They also find that increased school choice improves achievement but only up to a certain threshold, after which the opposite effect

\footnotetext{
${ }^{10}$ In another review article, Heyneman and Loxley (1983) suggest that school and teacher quality matters more for lower-income countries than for high-income ones. At the same time, family background matters for these countries less.

${ }^{11}$ This country included the same eight transition countries as the previous ones - the countries for which TIMSS data were available.

${ }^{12}$ The few studies on Ukraine are covered in the next section which focuses on the educational system in Ukraine
} 
takes place. Bukowska and Siwińska-Gorzelak (2011) find a significantly positive effect of school size in almost all their specifications. They also find a positive influence of school competition (and accordingly a negative effect of the Herfindahl index) on students' test scores.Finally, Jakubovsky and Sakowski (2006) find a small positive effect of school size and an inverse u-shaped effect of class size.

Kallai and Maniu (2004) estimate educational production functions for Romania. They found a positive effect of school size but no effect of class size on students' test scores. Porta (2011) using PISA data for Romania also finds that the smallest schools (first quintile) perform less well than bigger schools, but that the size of this effect is small and significant only for reading scores. A similar study for Serbia (MacDonald et al,2009) found similar small but significant effects for reading, math and science scores. Hermann (2004b) finds a negative effect of primary school size on the likelihood to entering a better secondary school in Hungary.

Summarizing, the large literature on the effects of class size and school size suggest that while class and school size might have an effect, these effects are unlikely to be large. For transition countries, school size, however, appears to be more significant than class size as a determinant of educational performance and, increasing school size appears to be, if any, beneficial for educational performance. At the same time, the literature also suggests that effects vary from one country to another, pointing to the need for more country-specific studies.

\section{The Educational System of Ukraine - Some Background}

In Ukraine the state is the main provider of education services, at all levels including general secondary education ${ }^{13}$ (GSE). Public schools constitute 99 percent of general secondary institutionseducating more than 99.5 percent of students. According to the data of the State Statistics Service of Ukraine the school network in the 2009/2010 school year consisted of 20.368 institutions: 2.177 level I schools (grades 1-4); 5.397 level I-II schools (grades 1-9); 12.312 level I-III schools (grades 1-12) ${ }^{14} ; 82$ level II-III schools; 389 special schools for children with disabilities (boarding schools) and 11 schools of social rehabilitation. Schoolsfor 'talented'

\footnotetext{
${ }^{13}$ In Ukraine general secondary education encompasses primary and secondary education.

${ }^{14}$ Including gymnasiums, lyceums and collegiums.
} 
students include 588 gymnasiums 386 lyceums 46 collegiums as well as the so called 'specialized' schools with more in-depth training in particular subjects.

Consolidating the network of general secondary education (GSE) schools has become an ever urging issue in Ukraine considering the demographic and financial situation in the country. Due to the demographic crisis the number of students in Ukrainian schools fell by 40 percent since independence while the number of schools only fell by 7 percent and the number of teachers by only 4 percent $^{15}$. As a consequence, Ukraine is maintaining a large network of small schools that have become smaller and smaller because of the severe drop in birth rates: 30 percent of level I schools have less than 10 students 21 percent of level I-II schools - less than 40 students; 17 percent of level I-III schools - less than 100 students $^{16}$. Overall 19.2 percent of schools are small as defined above and its overwhelming majority is located in rural areas. As a result budget resources while increasing over time mainly support the large network of institutions rather than being directed towards quality-enhancing inputs ${ }^{17}$.

\footnotetext{
${ }^{15}$ Around 510 thousand teachers work in the sector with 4.2 million students (compared to 537 thousand teachers and 7.1 million students in 1990/1991 school year).

${ }^{16}$ World Bank calculations based on a school-level database compiled on the basis of information provided by each of the oblasts and related jurisdictions for the 2009/2010 school year.

${ }^{17}$ See for details the Ukraine Public Finance Review (phase II) in FY 2007-08. Currently education sector expenditures account for almost a quarter of consolidated budget (24.8 percent in 2010) and 7.1 percent of GDP. In 2010, expenditures from the consolidated budget for education reached UAH 77.9 billion - a ten-time increase over the 2000 level. This increase exceeded the growth rate of the nominal amount of expenditures of the consolidated budget for these years which multiplied 6.5 times. The bulk of the consolidated budget is earmarked for salaries and utilities which are mainly intended to maintain budgetary institutions and thus crowd out other expenditures. At the same time wages in education remain lower than in many other sectors of the economy including manufacturing, transport, communications, financial services, retailing, etc. In Bulgaria, for example, resources saved thanks to consolidation of schools allowed to increase wages in the education sector by 46 percent between 2006 and 2008. Efficiency gains allowed also allocation of more resources for capital investment within the sector (http://www.worldbank.bg/WBSITE/EXTERNAL/COUNTRIES/ECAEXT/BULGARIAEXTN/0, contentMDK:226 99182 menuPK:305444 pagePK:2865066 piPK:2865079 theSitePK:305439,00.html).
} 
Figure 1: Trends in number of students teachers and schools in GSE in Ukraine 1990-2010

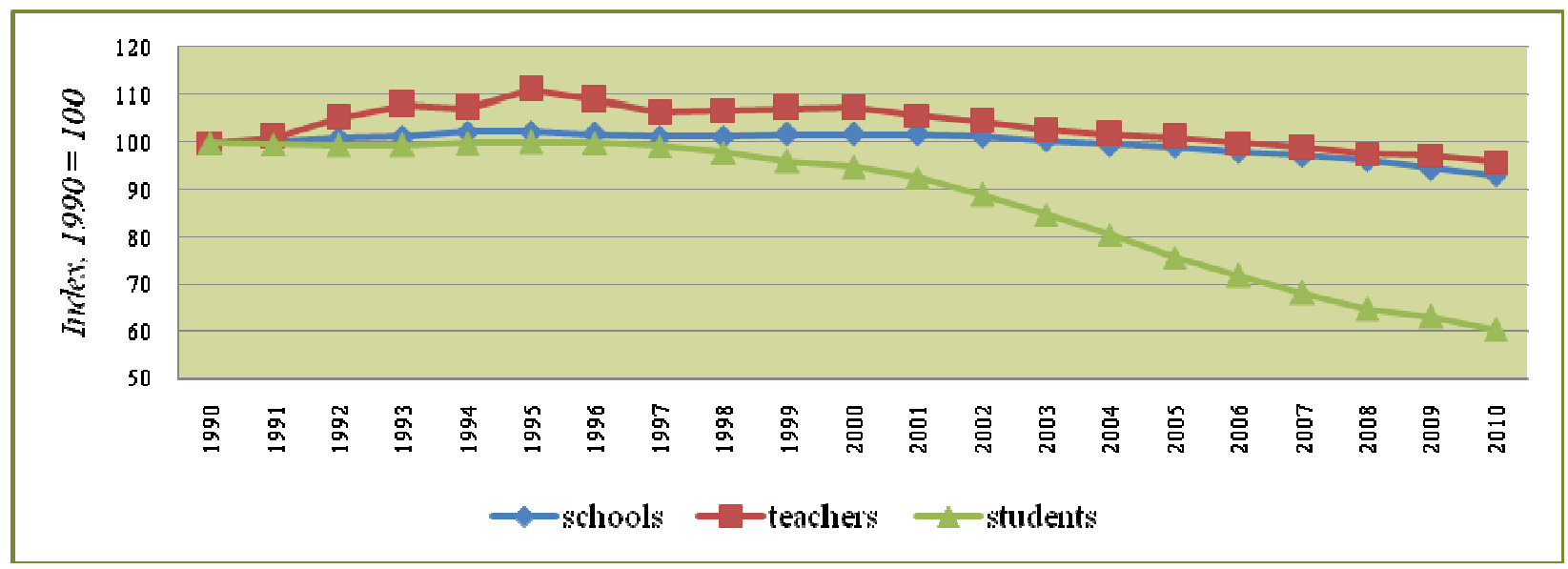

As a result of demographic decline the average school size dropped by one-third from 326.8 students per school back in 1990/1991 to 211.8 in 2010/2011 school year. Interestingly, the slump was most dramatic in urban areas where school size almost halved over the last two decades compared to a 27 percent decline in rural schools. While in 1990/1991 urban schools were about 5 times larger than rural schools, this ratio has decreased to about 4 .

Class-size has also been steadily decreasing and reached 18.1 students per class (23.2 - in urban areas and $12.5-$ in rural areas $)^{18}$.

In this paper, we investigate school-size and class-size effects on school performance in Ukraine using schools' graduates in Ukraine's External Independent Test (EIT) ${ }^{19}$. It is important to note that this test only covers part of the graduates of secondary schools.

- The EIT exams are only taken by upper secondary education graduates (grades 11-12), so we miss around 40 percent of lower secondary school graduates in urban areas and almost 50 percent in rural areas (see table 1). Most of them leave for vocational schools as an ultimate goal or as the transit route to the higher education institutions and thus omit the EIT exams. The share of students leaving after the $9^{\text {th }}$ grade significantly increased over the last three years which is likely to be the combination of EIT effect and expected enforcement of the

\footnotetext{
${ }^{18}$ The Law of Ukraine on General Secondary Education (Article 14) limits the class size to a maximum of 30 students and when there are less than 5 students in the schools in rural areas the individual training should apply to ensure quality. Classes may be split into groups for teaching particular subjects. Number of students in special schools (boarding schools) is defined by the Ministry of education and science, youth and sports of Ukraine by agreement with the Ministry of Health of Ukraine and the Ministry of Finance.

${ }^{19}$ This test became the key basis for entrance to higher education institutions in the country since 2008 .
} 
three year study in the upper secondary school that was envisaged until mid-2010. Thus, parents and students tried to avoid an extra year in the secondary school and to profit from the opportunity to get into the HEIs through the vocational schools (in some cases - with direct admission to the second or third year of study).

Table 1: Number of students that continue study in upper secondary daily schools

\begin{tabular}{|c|c|c|c|c|c|c|c|c|c|}
\hline \multirow{2}{*}{$\begin{array}{l}\text { Beginning of } \\
\text { the school } \\
\text { year }\end{array}$} & \multicolumn{3}{|c|}{ Total } & \multicolumn{3}{|c|}{ Urban areas } & \multicolumn{3}{|c|}{ Rural areas } \\
\hline & $\begin{array}{l}9^{\text {th }} \text { grade } \\
\text { graduates }\end{array}$ & $\begin{array}{c}\text { of them } \\
-10- \\
\text { graders }\end{array}$ & $\begin{array}{l}\text { percent of } \\
\text { students } \\
\text { continuing } \\
\text { study in } \\
\text { USS }\end{array}$ & $\begin{array}{l}9^{\text {th }} \text { grade } \\
\text { graduates }\end{array}$ & $\begin{array}{c}\text { of them } \\
-10- \\
\text { graders }\end{array}$ & $\begin{array}{l}\text { percent of } \\
\text { students } \\
\text { continuing } \\
\text { study in } \\
\text { USS }\end{array}$ & $\begin{array}{l}9^{\text {th }} \text { grade } \\
\text { graduates }\end{array}$ & $\begin{array}{c}\text { of them } \\
-10- \\
\text { graders }\end{array}$ & $\begin{array}{l}\text { percent of } \\
\text { students } \\
\text { continuing } \\
\text { study in } \\
\text { USS }\end{array}$ \\
\hline $2008 / 2009$ & 538,689 & 352,473 & 65.4 & 358,120 & 246,176 & 68.7 & 180,569 & 105,297 & 58.9 \\
\hline $2009 / 2010$ & 311,247 & 195,319 & 62.8 & 167,379 & 115,096 & 68.8 & 143,868 & 80,223 & 55.8 \\
\hline $2010 / 2011$ & 559,477 & 31,7099 & 56.7 & 37,1977 & 22,2072 & 59.7 & 187,500 & 95,027 & 50.7 \\
\hline $\begin{array}{l}\text { Average for } \\
\text { three-year } \\
\text { period }\end{array}$ & - & - & 61.4 & - & - & 65.0 & - & - & 54.8 \\
\hline
\end{tabular}

Source: State Statistics Service of Ukraine statistics bulletins on general secondary institutions in the relevant years.

- The EIT exams are only taken by those students who are interested in pursuing studies at the university level. For example, in 200984 percent of graduates participated in EIT in Ukrainian language and literature and in 2010 - 78 percent. A smaller number of students participate in the EIT in Ukrainian history, math and English (table 2).

Table 2: Participation of Ukrainian schools graduates in EIT in 2009-2010

\begin{tabular}{|c|c|c|c|c|c|c|c|c|c|}
\hline $\begin{array}{l}\text { School } \\
\text { Years }\end{array}$ & $\begin{array}{c}\text { Upper } \\
\text { secondary } \\
\text { education } \\
\text { graduates } \\
\text { (grades } \\
\text { 11-12) }\end{array}$ & $\begin{array}{c}\text { Participants } \\
\text { of EIT } \\
\text { (Ukrainian } \\
\text { language } \\
\text { and } \\
\text { literature) }\end{array}$ & $\begin{array}{c}\text { Share, } \\
\% \text { of } \\
\text { graduates }\end{array}$ & $\begin{array}{c}\text { Participants } \\
\text { of EIT in } \\
\text { (history of } \\
\text { Ukraine) }\end{array}$ & $\begin{array}{c}\text { Share, } \\
\%\end{array}$ & $\begin{array}{l}\text { Participants } \\
\text { of EIT in } \\
\text { (Math) }\end{array}$ & $\begin{array}{c}\text { Share, } \\
\%\end{array}$ & $\begin{array}{c}\text { Participants } \\
\text { of EIT in } \\
\text { (English) }\end{array}$ & $\begin{array}{c}\text { Share, } \\
\%\end{array}$ \\
\hline 2009 & 391,257 & 329,839 & 84.0 & 215,080 & 55.0 & 175,493 & 44.9 & 70,315 & 18.0 \\
\hline 2010 & 363,751 & 284,550 & 78.0 & 133,549 & 34.1 & 183,682 & 46.9 & 46,678 & 11.9 \\
\hline
\end{tabular}

Source: based on State Statistics Service of Ukraine statistics bulletins on general secondary institutions in the relevant years and official EITs reports of the Ukrainian Centre for Education Quality Monitoring.

- EIT is the main but not the only way for entering the higher education system. According to the Ministry of Education and Science of Ukraine in 2008 overall 91.2\% of students were admitted to the higher education institutions of III-IV level of accreditation on the basis of the EIT certificates ${ }^{20}$.

\footnotetext{
${ }^{20}$ Analytical note on results of the admission campaign in 2008 and major tasks for the organization of the admission process in 2009 (Annex to the decision of the board of the Ministry of Education and Science of Ukraine of 31.10.2008 № 12/2-4). Some of the tests were not developed in 2008 therefore the exams were conducted. For
} 
So far there has been little analysis of the EITdata. Besides the simple descriptive statistics in the annual EITreport, there are three studies that use EITdata.Kovtunets et al (undated) provide some analysis of whether the EITexam results predict performance during the first year at university. Muravyev and Talavera (2010) use the EITto see how an announced (but not implemented) language policy change has affected the subject choice and performance of students at minority language schools. The closest to the current paper is Coupé et al (2010) who use a sample of 300 schools to link EITscores to a wide set of input variables. They find a positive effect of school size and no effect of class size. The current paper extends that analysisby drawing on a much bigger sample of thousands of Ukrainian schools. The size of the current dataset not only provides for more precise estimates but also allows for the analysis of more precise questions, like an analysis by gender or by type of settlement. In addition, the current dataset allows us to analyze the Ukrainian plan to close schools with less than 100 students.

\section{Data and Analysis}

In this paper, we use several datasets which were matched and combined into one comprehensive dataset. From the Ministry of Education, we obtained data, for all Ukrainian schools, on the total number of students, the number of students by grade, the number of classes by grade and the total number of teachers and staff.

Data about performance on the EIT were obtained from the yearly public data files, posted on the EITsite, which provide, for each school, the distribution of students' scores over 10 intervals. In addition, from the Ukrainian Centre for Education Quality Monitoring we obtained mean and median scores data and information about the gender and the language choice of students ${ }^{21}$.

A more detailed description of these sources and the matching process can be found in the appendix A1.

example, tests in foreign languages - English, German, French and Spanish languages - were introduced in 2009. Other changes encompassed, for example, wider choice for participants (up to 5 subjects instead of only up to 3 in 2008) with reduced number of available subjects for testing ( 8 disciplines instead of 11).

${ }^{21}$ The correspondence between those two sources of data was high but not perfect. For a few schools, we had no mean scores and for somewhat more schools the total number of students according to the two databases was not equal, though such deviations were typically very small. One possible explanation for these differences is that the database of the Ministry's EIT Center is updated, f.e. correcting mistakes or including the results of appeals. 


\section{a. Descriptive Statistics for $2010^{22}$}

For 11683 Ukrainian schools we have information on both 2010 EITtest scores (from the EITdatabase) and information on input variables (from the Ministry of Education).

Given that our main variables of interest, school size and class size, but also other input variables are very different depending on whether or not the school is located in an urban or rural area, we provide the descriptive statistics for rural and urban schools separately.

For the descriptive statistics, we also focus on the most common type of schools, the 10361 'ordinary' schools ${ }^{23}$, to avoid mixing the effect of size and school type.

We further restrict our sample to those ordinary schools for which we have a complete set of 'credible' information, that is, they have scores on the Ukrainian exam, do have teachers and students, have a student-teacher ratio less than 50 and a class size less than $35^{24}$.

To illustrate the effect of school size and class size we divide the samples of rural and urban schools, into four intervals, each interval having approximately about a quarter of the observations. School size is measured by the total number of students at the school, class size is measured by the number of students in the final grade divided by the number of final grade classes (for a vast majority of schools this is the $11^{\text {th }}$ grade, for some it is the $12^{\text {th }}$ grade).

We use several indicators of school performance

- the mean score

- the median score

- $\quad$ the percentage of students scoring above 173

- $\quad$ the percentage of students scoring above 150

- $\quad$ the percentage of students score below 135.5

\footnotetext{
${ }^{22}$ The descriptive statistics for 2008 and 2009 give a qualitatively similar picture. Note that in this section we will only look at differences in means between groups, delaying the question of significance to the regression analysis.

${ }^{23}$ We do exclude 'ordinary' evening schools. For the regression analysis below, however, we do include all types of schools, controlling for differences through type-specific dummies.

${ }^{24}$ We lose about $5 \%$ of the schools by doing this, mainly rural schools.
} 
- we also compute a 'student participation ratio', that is, for those schools which have students that take the exam on a specific subject, we compute the ratio of students who take the exam divided by the total number of students in the highest grade ${ }^{25}$.

We also provide summary statistics for the explanatory variables we will use. We have two more measures of school inputs.

- Student-teacher ratio - the total number of students in the school divided by the total number of teachers in the school (these numbers are based on headcounts, not full time equivalents).

- $\quad$ Student-staff ratio - the total number of students in the school divided by the total number of teachers and non-teaching staff in the school (these numbers are based on headcounts, not full time equivalents).

We also have two measures of the group composition of the exam takers of each school.

- $\quad$ Language - the percentage of EITexams (other than the Ukrainian exam) taken in Ukrainian. Note that this reflects the language choice of the students taking the test and hence can differ from the language choice of the whole class.

- Gender Composition - the share of boys among those taking the EITexam. As not all students take the exam, this can differ from the share of boys in the class.

And we have two measures of the economic situation in the area (rayon) where the school is located.

- $\quad$ The unemployment rate at the end of 2009.

- $\quad$ The average wage at the end of 2009.

Finally, we have one measure at the level of the village where the school is located, that control for the possibility that bigger villages can have both bigger schools (because they have a bigger population) and better schools (because better teachers or 'better' parents might move to bigger villages with more amenities).

\footnotetext{
${ }^{25}$ We have this indicator for those schools that we were able to match to the MoE database. For some schools, we clearly have unrealistic participation ratios. We keep them in the sample here but will exclude these schools in further analysis - see below for details.
} 
- $\quad$ The population in the village where the school is located based on the 2001 population survey. For the big cities, we typically have population data for the district where the school is located.

Descriptive statistics are providedin Tables 3a (rural schools) and 3b (urban schools). 
Table 3a. Descriptive statistics for rural schools, by school size quartiles

\begin{tabular}{|c|c|c|c|c|c|c|c|c|c|c|c|c|}
\hline \multirow[t]{2}{*}{ Rural Schools } & \multicolumn{3}{|c|}{ First Quartile } & \multicolumn{3}{|c|}{ Second Quartile } & \multicolumn{3}{|c|}{ Third Quartile } & \multicolumn{3}{|c|}{ Fourth Quartile } \\
\hline & \# & Mean & Median & \# & Mean & Median & \# & Mean & Median & \# & Mean & Median \\
\hline Mean Score & 1529 & 148.83 & 148.80 & 1495 & 148.28 & 148.40 & 1514 & 148.65 & 148.50 & 1498 & 147.68 & 147.80 \\
\hline Median Score & 1529 & 146.98 & 147.00 & 1495 & 147.12 & 147.00 & 1514 & 147.77 & 148.00 & 1498 & 147.36 & 148.00 \\
\hline Percentage $>173$ & 1529 & 8.97 & 0.00 & 1495 & 9.08 & 0.00 & 1514 & 10.02 & 7.14 & 1498 & 10.12 & 7.69 \\
\hline Percentage $>150$ & 1529 & 48.41 & 50.00 & 1495 & 46.71 & 46.15 & 1514 & 48.23 & 50.00 & 1498 & 45.69 & 46.15 \\
\hline Percentage $<135.5$ & 1529 & 23.60 & 20.00 & 1495 & 25.36 & 23.81 & 1514 & 24.92 & 23.08 & 1498 & 27.79 & 25.93 \\
\hline Participation Ratio & 1529 & 69.85 & 70.00 & 1495 & 73.91 & 75.00 & 1514 & 73.30 & 75.00 & 1498 & 74.57 & 74.46 \\
\hline Exams Per Student & 1529 & 3.21 & 3.17 & 1495 & 3.22 & 3.18 & 1514 & 3.26 & 3.22 & 1498 & 3.31 & 3.29 \\
\hline $\mathrm{Nr}$ of Subjects & 1529 & 5.21 & 5.00 & 1495 & 5.70 & 6.00 & 1514 & 6.12 & 6.00 & 1498 & 6.99 & 7.00 \\
\hline \# Students & 1529 & 77.22 & 80.00 & 1495 & 120.06 & 119.00 & 1514 & 171.27 & 169.00 & 1498 & 326.27 & 288.00 \\
\hline \# Teachers & 1529 & 17.01 & 17.00 & 1495 & 20.31 & 20.00 & 1514 & 23.13 & 22.00 & 1498 & 36.02 & 34.00 \\
\hline \# Non-Teaching Staff & 1529 & 10.77 & 10.00 & 1495 & 12.79 & 12.00 & 1514 & 14.57 & 14.00 & 1498 & 19.66 & 18.00 \\
\hline Students/Teacher & 1529 & 4.59 & 4.57 & 1495 & 6.07 & 6.00 & 1514 & 7.61 & 7.48 & 1498 & 9.17 & 9.00 \\
\hline Students/Staff & 1529 & 2.82 & 2.81 & 1495 & 3.71 & 3.67 & 1514 & 4.66 & 4.60 & 1498 & 5.88 & 5.78 \\
\hline Class Size & 1529 & 8.70 & 8.00 & 1495 & 11.62 & 11.00 & 1514 & 14.76 & 14.00 & 1498 & 18.85 & 18.50 \\
\hline Share Ukrainian & 1529 & 0.93 & 1.00 & 1495 & 0.92 & 1.00 & 1514 & 0.89 & 1.00 & 1498 & 0.85 & 1.00 \\
\hline Share of Males & 1529 & 43.60 & 44.44 & 1495 & 43.66 & 42.86 & 1514 & 43.57 & 43.75 & 1498 & 41.77 & 41.67 \\
\hline Unemployment Rate in Rayon & 1529 & 3.45 & 3.20 & 1495 & 3.24 & 2.90 & 1514 & 2.79 & 2.50 & 1498 & 2.34 & 2.00 \\
\hline Average Wage in Rayon & 1529 & 1389.90 & 1330.00 & 1495 & 1390.30 & 1323.00 & 1514 & 1417.64 & 1338.00 & 1498 & 1457.92 & 1353.39 \\
\hline Population in 2001 & 1529 & 754.39 & 704.00 & 1495 & 1030.68 & 960.00 & 1514 & 1523.92 & 1350.00 & 1498 & 2718.11 & 2343.00 \\
\hline
\end{tabular}


Table 3b. Descriptive statistics for urban schools, by school size quartiles

\begin{tabular}{|c|c|c|c|c|c|c|c|c|c|c|c|c|}
\hline \multirow[t]{2}{*}{ Urban Schools } & \multicolumn{3}{|c|}{ First Quartile } & \multicolumn{3}{|c|}{ Second Quartile } & \multicolumn{3}{|c|}{ Third Quartile } & \multicolumn{3}{|c|}{ Fourth Quartile } \\
\hline & $\#$ & Mean & Median & $\#$ & Mean & Median & $\#$ & Mean & Median & \# & Mean & Median \\
\hline Mean Score & 994 & 147.50 & 147.00 & 976 & 150.32 & 150.10 & 983 & 152.28 & 152.10 & 980 & 154.75 & 154.50 \\
\hline Median Score & 994 & 146.75 & 146.00 & 976 & 150.00 & 149.50 & 983 & 152.35 & 152.00 & 980 & 155.18 & 155.00 \\
\hline Percentage $>173$ & 994 & 11.05 & 7.14 & 976 & 13.29 & 10.53 & 983 & 15.59 & 13.51 & 980 & 18.89 & 16.42 \\
\hline Percentage $>150$ & 994 & 44.75 & 43.48 & 976 & 50.47 & 50.00 & 983 & 54.68 & 54.29 & 980 & 60.06 & 60.00 \\
\hline Percentage $<135.5$ & 994 & 28.77 & 26.67 & 976 & 23.82 & 21.74 & 983 & 20.48 & 19.05 & 980 & 17.43 & 16.28 \\
\hline Participation Ratio & 994 & 83.27 & 82.35 & 976 & 87.95 & 88.89 & 983 & 92.06 & 91.43 & 980 & 96.64 & 93.17 \\
\hline Exams Per Student & 994 & 3.29 & 3.25 & 976 & 3.36 & 3.33 & 983 & 3.42 & 3.39 & 980 & 3.47 & 3.46 \\
\hline $\mathrm{Nr}$ of Subjects & 994 & 6.62 & 7.00 & 976 & 7.48 & 8.00 & 983 & 7.85 & 8.00 & 980 & 8.04 & 8.00 \\
\hline \# Students & 994 & 213.67 & 222.00 & 976 & 378.99 & 380.00 & 983 & 544.26 & 542.00 & 980 & 855.35 & 802.00 \\
\hline \# Teachers & 994 & 25.47 & 24.00 & 976 & 36.90 & 36.00 & 983 & 48.30 & 47.00 & 980 & 69.40 & 66.00 \\
\hline \# Non-Teaching Staff & 994 & 16.74 & 15.00 & 976 & 19.92 & 19.00 & 983 & 22.63 & 22.00 & 980 & 28.99 & 27.00 \\
\hline Students/Teacher & 994 & 8.66 & 8.81 & 976 & 10.64 & 10.56 & 983 & 11.64 & 11.53 & 980 & 12.59 & 12.55 \\
\hline Students/Staff & 994 & 5.29 & 5.40 & 976 & 6.91 & 6.86 & 983 & 7.88 & 7.79 & 980 & 8.86 & 8.75 \\
\hline Class Size & 994 & 17.07 & 17.00 & 976 & 21.04 & 20.50 & 983 & 22.34 & 22.00 & 980 & 24.00 & 24.00 \\
\hline Share Ukrainian & 994 & 0.68 & 0.97 & 976 & 0.69 & 0.97 & 983 & 0.72 & 0.98 & 980 & 0.74 & 0.98 \\
\hline Share of Males & 994 & 43.23 & 43.61 & 976 & 43.16 & 43.75 & 983 & 43.76 & 43.90 & 980 & 43.79 & 44.19 \\
\hline Unemployment Rate in Rayon & 994 & 1.99 & 1.65 & 976 & 2.11 & 1.70 & 983 & 1.99 & 1.70 & 980 & 1.72 & 1.50 \\
\hline Average Wage in Rayon & 994 & 1733.38 & 1707.00 & 976 & 1755.53 & 1679.00 & 983 & 1771.25 & 1732.60 & 980 & 1851.47 & 1795.00 \\
\hline Population in 2001 & 994 & 63189.65 & 32737.00 & 976 & 75172.65 & 49938.00 & 983 & 80115.54 & 52265.00 & 980 & 112160 & 103244 \\
\hline
\end{tabular}


Based on tables $3 \mathrm{a}$ and $3 \mathrm{~b}$, we find that

- The size distribution of urban and rural schools overlaps little. For rural areas, the school size quartile thresholds are at 100 students, 141 students and 209 students while for the urban schools, the thresholds are at 305 students, 458 students and 646 students. Hence, the lowest size quartile for urban schools has an upper limit that is higher than the lower limit of the highest size quartile of rural schools.

- $\quad$ In rural areas, the relation between size and Ukrainian exam scores is limited. Bigger schools have a slightly higher percentage of students among the top students, but also a somewhat higher percentage of low scoring students. The participation ratio, however, is somewhat lower in the lowest quartile.

- While performance does not change much as size increases in rural areas, input variables do change a lot: the schools in the top quartile have, on average, a class size that is about the double of the class size in schools in the lowest quartile. The same is true of the student-teacher ratio.

- In the cities, the relation between size and test scores is much clearer: bigger size goes together with substantially better mean and median test scores, a higher percentage of high scoring students and a lower percentage of low scoring students. For example, while the lowest urban size quartile has an average mean score of 147.5 and 44.75 percent students scoring 'above average', the top quartile has an average mean score of 154.75 and 60 percent students scoring 'above average'. In addition, schools in the upper quartiles have substantially higher participation rates than schools in the lower quartiles.

- Besides performance increasing with the size of the school in urban areas, also the class size and the student-teacher ratio increase with the size of the school.

Given that bigger schools in urban areas perform better, on average, than smaller schools in urban areas, and that, on average, schools in rural areas are smaller than schools in urban areas, it is no surprise that schools in rural areas perform worse, on average, than schools in urban areas. The participation ratio is also substantially smaller in rural areas ${ }^{26}$.

\footnotetext{
${ }^{26}$ More general, if we compare rural schools to urban schools, we find that the median rural school has 9 students taking the EIT tests against 34 students in urban schools, reflecting the big differences in size between rural and urban schools. Rural Schools have lower mean and median scores (about 148 versus about 153). They have a
} 
Note that if we would focus on performance inMathematics or Ukrainian history, rather than on the Ukrainian test, we get similar results.

As explained in the introduction, Ukraine plans to close schools with less than 100 students $^{27}$. About a quarter of rural areas fall in this category, indeed, the upper bound of the bottom quartile of school size in our sample happens to be 100 . The above results suggest that students at these smaller schools are not underperforming in test scores (nor are they over-performing), though they do require substantially more inputs and have somewhat smaller participation rates.

Very few schools in urban areas have less than 100 students (about 1 percent of the urban sample). The descriptive statistics above, however, do suggest that in urban areas increasing school size can increase both quality and save on inputs. This is unlike the descriptive statistics for the rural areas, which suggest that inputs can be saved (at a bigger rate than in urban areas) by having bigger schools but also, that quality would not change much.

In table $4 \mathrm{a}$ and $4 \mathrm{~b}$, we do a similar exercise as before but using class size quartiles.

- $\quad$ For rural schools, we see little differences among quartiles, though participation is lower in the highest class size quartile.

- For urban schools, participation is lower in the highest class size quartile but the lowest class size quartile has a lower average score and more failing students.

- Classes in urban areas are substantially bigger than classes in rural areas. Quartile thresholds are at 17.5, 21 and 25 students per class for urban areas and 9,13 and 17 students per class in rural areas.

considerably lower percentage of students who get top grades (median of $4.76 \%$ vs $14.28 \%$ ) or who get above average grades (median of $48 \%$ vs $57 \%$ ) but a considerably higher percentage of students who get low scores (median of $23.5 \%$ vs $17.5 \%$ ). Finally, $73 \%$ of the median rural school's students participate in the EIT, against $91 \%$ at the median urban school. Not surprisingly, the population in communities where rural schools are located is much smaller (median slightly 1000 people) than the urban communities (median around 70000). Not surprisingly, rural schools are substantially smaller than urban schools (median total number of students of 142 versus 466 ), have somewhat less teachers and non-teaching staff leading to a student-teacher ratio (median 6.6 versus 10.7), a student staff ratio (median 4 versus 7.2) and class size (median of 13 versus 21.5) which are substantially lower in rural areas. At the other side, students of urban schools are more likely to choose other languages than Ukrainian to do the EIT and are located in areas with less unemployment and higher wages. Both in rural and urban areas, the share of boys is around 43 percent, suggesting there is quite a gap in the decision to continue to study.

${ }^{27}$ Given our performance measure is based on a test taken by school graduates, we do not have schools of level I or level I-II in our sample. 
Table 4a. Descriptive statistics for rural schools, by class size quartiles

\begin{tabular}{|c|c|c|c|c|c|c|c|c|c|c|c|c|}
\hline \multirow[t]{2}{*}{ Rural Schools } & \multicolumn{3}{|c|}{ First Quartile } & \multicolumn{3}{|c|}{ Second Quartile } & \multicolumn{3}{|c|}{ Third Quartile } & \multicolumn{3}{|c|}{ Fourth Quartile } \\
\hline & $\#$ & Mean & Median & \# & Mean & Median & $\#$ & Mean & Median & $\#$ & Mean & Median \\
\hline Mean Score & 1839 & 148.69 & 148.80 & 1487 & 148.45 & 148.50 & 1248 & 148.24 & 148.30 & 1462 & 147.96 & 148.10 \\
\hline Median Score & 1839 & 146.62 & 147.00 & 1487 & 147.48 & 148.00 & 1248 & 147.77 & 148.00 & 1462 & 147.60 & 148.00 \\
\hline Percentage $>173$ & 1839 & 9.11 & 0.00 & 1487 & 9.34 & 0.00 & 1248 & 9.62 & 7.69 & 1462 & 10.25 & 7.69 \\
\hline Percentage $>150$ & 1839 & 47.81 & 50.00 & 1487 & 47.75 & 50.00 & 1248 & 47.15 & 46.67 & 1462 & 46.21 & 46.29 \\
\hline Percentage $<135.5$ & 1839 & 24.26 & 20.00 & 1487 & 24.56 & 22.22 & 1248 & 25.81 & 25.00 & 1462 & 27.37 & 25.00 \\
\hline Participationratio & 1839 & 74.38 & 75.00 & 1487 & 73.85 & 75.00 & 1248 & 73.25 & 75.00 & 1462 & 69.74 & 71.75 \\
\hline Exams Per Student & 1839 & 3.20 & 3.17 & 1487 & 3.24 & 3.20 & 1248 & 3.28 & 3.25 & 1462 & 3.29 & 3.26 \\
\hline Nr of Subjects & 1839 & 5.04 & 5.00 & 1487 & 5.87 & 6.00 & 1248 & 6.47 & 7.00 & 1462 & 6.94 & 7.00 \\
\hline \# Students & 1839 & 106.92 & 96.00 & 1487 & 136.87 & 125.00 & 1248 & 196.17 & 170.50 & 1462 & 274.06 & 234.00 \\
\hline \# Teachers & 1839 & 18.98 & 18.00 & 1487 & 21.26 & 20.00 & 1248 & 25.67 & 23.00 & 1462 & 31.99 & 29.00 \\
\hline \# Non-Teaching Staff & 1839 & 12.01 & 11.00 & 1487 & 13.35 & 13.00 & 1248 & 15.67 & 14.50 & 1462 & 17.51 & 16.00 \\
\hline Students/Teacher & 1839 & 5.53 & 5.21 & 1487 & 6.39 & 6.16 & 1248 & 7.51 & 7.37 & 1462 & 8.43 & 8.26 \\
\hline Students/Staff & 1839 & 3.39 & 3.21 & 1487 & 3.91 & 3.78 & 1248 & 4.64 & 4.50 & 1462 & 5.39 & 5.24 \\
\hline Class Size & 1839 & 7.04 & 7.00 & 1487 & 11.43 & 11.00 & 1248 & 15.49 & 15.50 & 1462 & 21.88 & 21.00 \\
\hline Share Ukrainian & 1839 & 0.91 & 1.00 & 1487 & 0.90 & 1.00 & 1248 & 0.87 & 1.00 & 1462 & 0.89 & 1.00 \\
\hline Share of Males & 1839 & 43.72 & 42.86 & 1487 & 43.46 & 44.44 & 1248 & 43.21 & 42.86 & 1462 & 42.08 & 42.31 \\
\hline Unemployment Rate in Rayon & 1839 & 3.24 & 2.90 & 1487 & 3.03 & 2.70 & 1248 & 2.80 & 2.50 & 1462 & 2.66 & 2.30 \\
\hline Average Wage in Rayon & 1839 & 1405.11 & 1336.00 & 1487 & 1404.92 & 1328.00 & 1248 & 1417.27 & 1338.00 & 1462 & 1430.95 & 1338.63 \\
\hline
\end{tabular}


Table $4 b$. Descriptive statistics for urban schools, by class size quartiles

\begin{tabular}{|c|c|c|c|c|c|c|c|c|c|c|c|c|}
\hline Urban Schools & \multicolumn{3}{|c|}{ First Quartile } & \multicolumn{3}{|c|}{ Second Quartile } & \multicolumn{3}{|c|}{ Third Quartile } & \multicolumn{3}{|c|}{ Fourth Quartile } \\
\hline Mean Score & 1022 & 149.93 & 149.95 & 957 & 151.56 & 151.20 & 996 & 151.87 & 152.20 & 958 & 151.51 & 151.20 \\
\hline Median Score & 1022 & 149.35 & 149.50 & 957 & 151.45 & 151.50 & 996 & 152.00 & 152.00 & 958 & 151.50 & 151.50 \\
\hline Percentage $>173$ & 1022 & 13.42 & 10.00 & 957 & 15.09 & 12.20 & 996 & 15.47 & 13.64 & 958 & 14.84 & 12.75 \\
\hline Percentage $>150$ & 1022 & 50.00 & 50.00 & 957 & 52.94 & 53.33 & 996 & 53.96 & 54.55 & 958 & 53.06 & 53.44 \\
\hline Percentage $<135.5$ & 1022 & 24.93 & 21.95 & 957 & 22.18 & 20.00 & 996 & 21.48 & 19.62 & 958 & 21.88 & 20.00 \\
\hline Participationratio & 1022 & 96.95 & 88.12 & 957 & 86.38 & 90.00 & 996 & 87.87 & 91.11 & 958 & 88.25 & 91.05 \\
\hline Exams Per Student & 1022 & 3.31 & 3.30 & 957 & 3.38 & 3.38 & 996 & 3.41 & 3.41 & 958 & 3.43 & 3.41 \\
\hline Nr of Subjects & 1022 & 6.84 & 7.00 & 957 & 7.58 & 8.00 & 996 & 7.79 & 8.00 & 958 & 7.80 & 8.00 \\
\hline \# Students & 1022 & 325.10 & 293.00 & 957 & 474.63 & 446.00 & 996 & 571.38 & 554.50 & 958 & 626.28 & 573.50 \\
\hline \# Teachers & 1022 & 34.59 & 31.00 & 957 & 44.01 & 41.00 & 996 & 49.67 & 47.00 & 958 & 52.06 & 48.00 \\
\hline \# Non-Teaching Staff & 1022 & 19.23 & 17.00 & 957 & 21.99 & 20.00 & 996 & 23.21 & 22.00 & 958 & 23.93 & 22.00 \\
\hline Students/Teacher & 1022 & 9.21 & 9.40 & 957 & 10.82 & 10.72 & 996 & 11.54 & 11.54 & 958 & 12.02 & 12.10 \\
\hline Students/Staff & 1022 & 5.91 & 5.99 & 957 & 7.14 & 7.16 & 996 & 7.80 & 7.75 & 958 & 8.13 & 8.08 \\
\hline Class Size & 1022 & 13.69 & 15.00 & 957 & 19.54 & 19.50 & 996 & 23.21 & 23.00 & 958 & 28.38 & 28.00 \\
\hline Share Ukrainian & 1022 & 0.71 & 1.00 & 957 & 0.73 & 1.00 & 996 & 0.72 & 0.96 & 958 & 0.68 & 0.88 \\
\hline Share of Males & 1022 & 42.96 & 43.48 & 957 & 43.74 & 44.44 & 996 & 43.49 & 43.75 & 958 & 43.79 & 44.00 \\
\hline Unemployment Rate in Rayon & 1022 & 2.19 & 1.80 & 957 & 2.04 & 1.70 & 996 & 1.91 & 1.60 & 958 & 1.65 & 1.35 \\
\hline Average Wage in Rayon & 1022 & 1676.80 & 1542.10 & 957 & 1758.29 & 1688.90 & 996 & 1807.38 & 1763.00 & 958 & 1874.15 & 1877.00 \\
\hline Population in 2001 & 1022 & 51378 & 17516.00 & 957 & 76705 & 51552.00 & 996 & 90898 & 72611.00 & 958 & 113152 & 105654.00 \\
\hline
\end{tabular}


Of course, none of the above results controls for other explanatory variables that can influence the school's performance measures. The regression analysis presented below will analyze whether these preliminary findings are confirmed once one controls for such confounding factors.

\section{b. $\quad$ Are there selection effects?}

Before we can study the determinants of the test scores, we need to discuss a number of sample selection issues as sample selection has the potential to bias our regression estimates.

We have data on12,075 schools participating in the $2010 \mathrm{EIT}^{28}$. In the MOE database, however, we only have 11,950 schools which have students in the $11^{\text {th }}$ and/or $12^{\text {th }}$ grade in 2010 . For 11683 schools we have information in both databases, implying we have data for at least 94.5 percent of the Ukrainian schools with graduating students $(11,683 /(11,683+(12,075-$ $11,683)+(11,950-11,683)))$. Another implication is that almost all schools which have students in the last year of secondary education have students who participate in the EIT. Hence, the 'selection' introduced by the fact that we use EIT results, which is only taken by students aiming to go to the university, rather than some general test which would be taken by all graduating students, is likely to be minor. Of course, there is also the issue of selection among the students, an issue we will discuss next.

Only those students interested in continuing their studies at a university within Ukraine have an interest in taking the Independent External Test, hence the school average we have are based on a selected group of students rather than all students graduating in a given year. Moreover, while the students take the decision to participate or not themselves, schools do have a possibility to try to influence this choice. For example, if a school would like to get a good average score on the EIT, it can try to persuade weaker students not to take the test.

\footnotetext{
${ }^{28}$ We have 12267 schools in the EIT 2009 data and 13678 in the EIT 2008 data. The 2008 EIT database includes vocational schools, which is not the case in 2009 and 2010. In this section, we focus on the descriptive data for the 2010 EIT. The descriptive statistics for 2008 and 2009 give a qualitatively similar picture
} 
To study the degree to which there is selection, we use the 'student participation ratio', that is, for those schools which have students that take the exam on a specific subject, we compute the ratio of students who take the exam divided by the total number of students in the highest grade (for a vast majority of schools this is the $11^{\text {th }}$ grade, for some it is the $12^{\text {th }}$ grade). Given that all students that participate in the EIT take the Ukrainian exam, a school's ratio of the number of students that take the Ukrainian exam on the number of students in the highest year is a good proxy for the extent of selection. If this ratio is 1 , it means all students participate, if it is 0 it means nobody participates.

In about $7 \%$ of the cases, the participation ratio indicator is bigger than one, i.e. there are more students taking the test than there are in the $11^{\text {th }} / 12^{\text {th }}$ grade. One explanation for this is that the MoE data were recorded at a different time than the EIT exams, and that some students might have changed schools between the recording of the MoE data and the EIT exams. A second possible explanation is that some graduates of previous years were allocated to the school were they graduated in the past. A third explanation is simply that there are mistakes in the database. In the regression analysis presented below, we include in the sample only schoolswith a participation ratio that is less than 101 percent.

Table 5 gives the 2010 participation ratio statistics by region - we see a substantial variation among oblasts with especially low rates of participation in the Western regions of Zakarpatiaand Chernivtsi (between 60 and 70 percent) and high rates of participation in Sevastopol and especially Kyiv (over 90 percent).

Table 6 tries to explain the differences between schools in terms of the 2010 participation ratio. We firstrun a simple OLS regression (1) of the participation ratio on our main variables of interest and a set of dummies reflecting the settlement status (urban versus rural), the oblast in which the school is located and the type of the school. Then (2) we add a set of additional explanatory variables including the gender composition of the school's EIT participant, their language choice, the school's location population in 2001, and the average wage and the unemployment rate in the rayon where the school is located in 2009. Next (3) we allow for nonlinear effects in our main input variables, adding squared terms of the total number of students, the student-teacher ratio at the school and the class size of the graduating class. Finally, we use tobit regression (4) to control for the fact that the participation ratio is constrained to be between 
zero and one. We run these four regressions first on the total sample and then we run separate regressions for urban and rural schools. 
Table 5 - Participation Ratio by Oblast

\begin{tabular}{|c|c|c|c|c|c|c|}
\hline Region & \# & Mean & Median & St. Dev. & Min & Max \\
\hline Zakarpatska Oblast & 843 & 60.7 & 60.0 & 24.6 & 3.3 & 100.0 \\
\hline Chernivetska Oblast & 754 & 67.9 & 69.6 & 22.2 & 6.7 & 100.0 \\
\hline Volynska Oblast & 1027 & 74.5 & 77.3 & 20.3 & 1.9 & 100.0 \\
\hline Khersonsksa Oblast & 982 & 74.2 & 78.0 & 21.7 & 4.7 & 100.6 \\
\hline Ivano-Frankivska Oblast & 975 & 76.1 & 79.5 & 19.7 & 9.1 & 101.0 \\
\hline Rivnenska Oblast & 1012 & 76.6 & 80.0 & 20.6 & 12.5 & 101.0 \\
\hline Chernihivska Oblast & 1116 & 77.2 & 82.4 & 21.0 & 3.8 & 100.0 \\
\hline Odeska Oblast & 1638 & 77.9 & 84.6 & 21.4 & 1.6 & 101.0 \\
\hline Khmelnytska Oblast & 1280 & 78.5 & 84.6 & 21.3 & 1.9 & 100.0 \\
\hline Cherkaska Oblast & 1339 & 80.4 & 85.4 & 19.2 & 2.0 & 100.0 \\
\hline Zaporizka Oblast & 1309 & 79.3 & 85.7 & 21.4 & 2.4 & 100.0 \\
\hline Kirovogradska Oblast & 1053 & 79.2 & 85.7 & 20.8 & 9.1 & 100.9 \\
\hline Vinnytska Oblast & 1389 & 81.2 & 86.7 & 18.6 & 4.0 & 101.0 \\
\hline Mykolaivska Oblast & 1049 & 80.3 & 86.7 & 21.5 & 2.9 & 100.9 \\
\hline Autonomous Republic of Crimea & 1189 & 80.9 & 87.2 & 19.5 & 0.9 & 100.0 \\
\hline Zhytomyrska Oblast & 944 & 80.9 & 87.5 & 20.1 & 4.3 & 100.0 \\
\hline Lvivska Oblast & 1678 & 82.0 & 87.7 & 18.4 & 2.0 & 100.9 \\
\hline Poltavska Oblast & 1229 & 83.0 & 88.2 & 18.0 & 7.4 & 100.0 \\
\hline Ternopilska Oblast & 813 & 83.0 & 88.4 & 18.4 & 1.6 & 100.0 \\
\hline Donetska Oblast & 2363 & 82.4 & 89.5 & 20.2 & 0.4 & 100.7 \\
\hline Sumska Oblast & 997 & 82.8 & 89.5 & 18.9 & 1.8 & 100.8 \\
\hline Dnipropetrovska Oblast & 2098 & 84.1 & 90.0 & 17.6 & 1.0 & 101.0 \\
\hline Kyivska Oblast & 1420 & 83.7 & 90.0 & 18.5 & 2.6 & 100.9 \\
\hline Luhanska Oblast & 1258 & 84.6 & 90.5 & 17.3 & 7.2 & 100.9 \\
\hline Kharkivska Oblast & 1870 & 85.5 & 91.7 & 17.1 & 12.5 & 100.0 \\
\hline City of Sevastopol & 170 & 85.5 & 91.8 & 16.6 & 20.8 & 100.0 \\
\hline City of Kyiv & 1033 & 92.4 & 96.4 & 13.5 & 0.4 & 100.9 \\
\hline
\end{tabular}


Table 6: Ukrainian Language, Participation Ratio

\begin{tabular}{|c|c|c|c|c|c|c|c|c|c|c|c|c|}
\hline & \multicolumn{4}{|c|}{ Total } & \multicolumn{4}{|c|}{ Urban } & \multicolumn{4}{|c|}{ Rural } \\
\hline & (1) & (2) & (3) & (4) & (1) & (2) & (3) & (4) & (1) & (2) & (3) & (4) \\
\hline \multirow[t]{2}{*}{ \# students } & $0.014 * * *$ & $0.013 * * *$ & $0.031 * * *$ & $0.031 * * *$ & $\begin{array}{c}0.014 * * \\
*\end{array}$ & $0.014 * * *$ & $0.038 * * *$ & $0.038 * * *$ & $\begin{array}{c}0.010^{* *} \\
*\end{array}$ & $0.008 * *$ & $0.048^{* * *}$ & $0.053 * * *$ \\
\hline & 16.05 & 15.35 & 11.22 & 8.66 & 16.61 & 16.3 & 12.55 & 11.87 & 2.66 & 1.97 & 4.34 & 4.51 \\
\hline \multirow[t]{2}{*}{ (\# students) ${ }^{2}$} & & & $-0.000 * * *$ & $-0.000 * * *$ & & & $-0.000 * * *$ & $-0.000 * * *$ & & & $-0.000 * * *$ & $-0.000 * * *$ \\
\hline & & & -7.8 & -5.49 & & & -9.57 & -8.33 & & & -3.64 & -4.07 \\
\hline \multirow[t]{2}{*}{ Student/Teacher } & $0.173 *$ & $0.204 * *$ & $0.626^{* *}$ & $0.737 * * *$ & 0.108 & 0.115 & 0.455 & $0.502 *$ & $\begin{array}{c}0.565^{* *} \\
*\end{array}$ & $0.571 * * *$ & $1.348^{* *}$ & $1.478^{* *}$ \\
\hline & 1.83 & 2.15 & 2.4 & 2.83 & 1.09 & 1.15 & 1.44 & 1.8 & 2.68 & 2.72 & 2.03 & 2.41 \\
\hline \multirow[t]{2}{*}{$(\text { Stud./Teacher })^{2}$} & & & $-0.031 * * *$ & $-0.034 * * *$ & & & $-0.022 * *$ & $-0.023 * *$ & & & $-0.082 * *$ & $-0.088 * * *$ \\
\hline & & & -2.94 & -3.28 & & & -2.13 & -2.35 & & & -2.2 & -2.69 \\
\hline \multirow[t]{2}{*}{ Class Size } & 0.017 & 0.016 & 0.057 & $-0.247 *$ & $\begin{array}{c}0.147^{* *} \\
*\end{array}$ & $0.156^{* * *}$ & -0.169 & $-0.444 * *$ & -0.048 & -0.059 & $0.727^{* * *}$ & $0.398^{*}$ \\
\hline & 0.49 & 0.45 & 0.39 & -1.79 & 3.32 & 3.38 & -0.59 & -2.23 & -0.85 & -1.04 & 3.27 & 1.78 \\
\hline \multirow[t]{2}{*}{$(\text { Class Size })^{2}$} & & & -0.003 & 0.003 & & & 0.006 & $0.012 * *$ & & & $-0.028 * * *$ & $-0.021 * * *$ \\
\hline & & & -0.92 & 0.85 & & & 0.91 & 2.54 & & & -4.29 & -3.16 \\
\hline \multirow[t]{2}{*}{ urban==1 } & $8.773 * * *$ & $8.529 * * *$ & $7.295^{* * *}$ & $8.164 * * *$ & & & & & & & & \\
\hline & 17.39 & 16.81 & 13.33 & 13.41 & & & & & & & & \\
\hline \multirow[t]{2}{*}{ Gender Comp. } & & $0.089 * * *$ & $0.089 * * *$ & $0.093 * * *$ & & $0.041 *$ & $0.042 *$ & $0.039 * *$ & & $0.102 * * *$ & $0.102 * * *$ & $0.108 * * *$ \\
\hline & & 6.54 & 6.62 & 8.91 & & 1.76 & 1.82 & 2.46 & & 6.24 & 6.32 & 7.81 \\
\hline \multirow[t]{2}{*}{$\begin{array}{c}\text { Unemployment rate } \\
\text { 2nno }\end{array}$} & & $0.544 * * *$ & $0.561^{* * *}$ & $0.602 * * *$ & & $0.384^{* *}$ & 0.285 & 0.308 & & $0.555^{* * *}$ & $0.628 * * *$ & $0.688 * * *$ \\
\hline & & 4.03 & 4.16 & 4.2 & & 2.15 & 1.6 & 1.58 & & 3.02 & 3.44 & 3.4 \\
\hline \multirow[t]{2}{*}{ Average Wage 2009} & & $0.002 * * *$ & $0.002 * * *$ & $0.002 * * *$ & & 0 & 0 & 0 & & $0.003 * * *$ & $0.003 * * *$ & $0.004 * * *$ \\
\hline & & 3.34 & 3.54 & 2.66 & & 0.02 & 0.24 & 0.09 & & 3.85 & 3.88 & 2.99 \\
\hline \multirow[t]{2}{*}{ Population } & & 0.003 & $0.008 * *$ & $0.010^{* *}$ & & 0.001 & 0.004 & 0.005 & & $0.310^{*}$ & $0.334 * *$ & $0.348 * * *$ \\
\hline & & 1.14 & 2.54 & 2.26 & & 0.45 & 1.13 & 1.43 & & 1.95 & 2.29 & 3.48 \\
\hline \multirow[t]{2}{*}{ Share Ukrainian } & & $0.016^{*}$ & $0.017 * *$ & $0.021 * *$ & & 0.014 & 0.014 & $0.019^{*}$ & & 0.016 & 0.018 & 0.017 \\
\hline & & 1.87 & 1.99 & 2.3 & & 1.26 & 1.27 & 1.93 & & 1.15 & 1.25 & 1.19 \\
\hline \multirow[t]{2}{*}{ _cons } & $\begin{array}{c}75.101 * * \\
*\end{array}$ & $67.172 * * *$ & $63.185^{* * *}$ & $68.108 * * *$ & $\begin{array}{c}82.443^{*} \\
* * \\
\end{array}$ & $79.378^{* * *}$ & $76.311 * * *$ & $81.290^{* * *}$ & $\begin{array}{c}70.735^{*} \\
* * \\
\end{array}$ & $\begin{array}{c}59.646^{* *} \\
*\end{array}$ & $47.878 * * *$ & $50.930 * * *$ \\
\hline & 63.76 & 43.18 & 31.22 & 30.41 & 52.81 & 37.89 & 22.19 & 28.73 & 23.71 & 18.3 & 12.1 & 9.75 \\
\hline sigma & & & & $18.866^{* * *}$ & & & & $14.110^{* * *}$ & & & & $21.698 * * *$ \\
\hline
\end{tabular}




\begin{tabular}{|c|c|c|c|c|c|c|c|c|c|c|c|c|}
\hline & & & & 134.82 & & & & 90.1 & & & & 100.17 \\
\hline R Adj sq. & 0.309 & 0.316 & 0.32 & & 0.447 & 0.448 & 0.459 & & 0.083 & 0.098 & 0.107 & \\
\hline $\mathrm{N}$ & 10906 & 10906 & 10906 & 10906 & 4922 & 4922 & 4922 & 4922 & 5984 & 5984 & 5984 & 5984 \\
\hline
\end{tabular}

The regression also includes oblast dummies, dummies for different types of schools and evening schools. The full table can be found in excel tables which can be made available upon request. *** means significant at the $1 \%$ level, ** at the $5 \%$ level and $*$ at the 10 percent level.T statistics are based on robust standard errors for the OLS specifications. 
We find that

- School size is positively correlated with the participation-ratio in both rural and urban areas, though the effect is somewhat smaller in the rural areas. When allowing for a nonlinear effect of school size (specification 3), we find, based on the complete sample, that the maximum participation ratio is reached at 1156 students, which is close to the $98^{\text {th }}$ percentile of school sizes in our sample. A school at this level has a participation ratio that is roughly 7 percentage points higher than a school of 455 students ( $75^{\text {th }}$ percentile), 11 percentage point more than a school at the median (227) and 14 percentage point more than a school of 128 students ( the $25^{\text {th }}$ percentile). Note that we get these effects after correcting for a wide range of other factors that can affect a school's participation ratio.

When restricting the sample to urban schools, we get the maximum at 1060 student $\left(95^{\text {th }}\right.$ percentile). A school at this level can expect a participation ratio that is 3,6 and 10 percentage point higher than a school with 666, 465 and 305 students respectively.

When restricting the sample to rural schools, we get the maximum at 470 students (between $95^{\text {th }}$ and $99^{\text {th }}$ percentile). A School at this level can expect a participation ratio that is $3.5,5.7$ and 7 percentage point higher than a school with 208, 141 respectively 100 students.

- The impact of class size varies from one specification to another, both in terms of significance and in terms of sign. In any case, even if significant, the size of the effect is very small.

We also find that:

- The student-teacher ratio has a positive effect in all specifications, indicating that schools with a higher number of students per teacher have higher participationratios. However, this effect is small in general and even insignificant for the urban schools. In rural schools, we find some evidence of a non-linear effect, with the optimal studentteacher ratio being around the $75^{\text {th }}$ percentile at 8 students per teacher. But again, deviating from that optimum barely reduces the participation ratio

- As far as other variables are concerned we find that evening schools have low participation ratios (70 percentage points less than the average school) and that urban schools have substantially higher participation rates ( about 8 percentage points). Also the type of school matters: lycea, colegiums and gymnasiums have significantly higher participation ratios (5 to 10 percentage points higher than ordinary schools). Schools located in rayons with higher registered unemployment have somewhat higher 
participation ratios as do schools located in rayons with higher wages and as do rural schools located in bigger villages.

- Interesting to note is the finding that schools that have a high percentage of males among the EIT participants are also schools that have a somewhat higher participation ratio. Note that this gender effect is much stronger than the language effect - having a higher percentage of students choosing Ukrainian as test language participate in the EIT goes together with only slightly more students participating and this effect is not statistically significant. This suggests that the Ukrainian language test does not scare off those more comfortable speaking Russian. At the same time, the fact that these gender and language ratios are computed based on the test takers rather than on all the students of the graduating class, is likely to introduce a bias in our estimates. Assume for example the extreme situation where all Russian speakers would prefer not to participate rather than taking the Russian language option, then our test based measure would indicate wrongly that the school is all Ukrainian speaking. A simple simulation indicated however, that this (non-random)error-in-variable bias tends to inflate the absolute value of the effect but in most cases only slightly so (less than 10 percent when we take a simulation set up that is similar to the data we have), especially when participation rates of the two groups are not too dissimilar (see appendix).

So far we have discussed the selection of schools into our sample and the selection of students into the test. One additional selection issue is related to the selection of students into schools. Indeed, it is possible that better students prefer to study at the bigger (or smaller) schools or that better students are put into smaller (bigger) classes.In other words, correlation does not necessarily mean causality.Like Urquiola (2006) noticed for Bolivia, also in rural Ukraine there is very often only one school with one class per grade, which reduces the possibility of students to select into schools, and of schools to select students into classes. Hence, our estimates for rural areas should provide 'cleaner' estimates of the effect of school size and class size on performance. In addition, class size is governed by maximum class size laws which also contribute to the exogeneity of class size. Still, one should be careful when interpreting our results in a causal way.

\section{c. Estimating Educational Production Functions}

We next run regressions using the same set of explanatory variables but with the mean test score of the school as a dependent variable.Since our dependent variable has no observations at the limit, there is no need for a Tobitregression, instead we add the participation ratio in 
specification (4) to control for possible selection effects. We focus first on the score on the Ukrainian exam, and then on the score on the mathematics and the history exam, two exams in which almost all schools participate ${ }^{29}$.

We find that (table 7)

- School size has a significantly positive effect on the school's mean Ukrainian exam score in all specifications, though the effect is clearly stronger for urban schools. Using the non-linear OLS specification, an urban school at the $25^{\text {th }}$ percentile of the school size distribution has an expected mean score that is 2 points less than a school at the $50^{\text {th }}$ percentile, and 4 points less than a school at the $75^{\text {th }}$ percentile. For rural schools, the difference between the $25^{\text {th }}$ and the $75^{\text {th }}$ percentile is only 1 point.

- Class size has a negative effect in all but one specification and this effect is statistically significant. However, the size of these effects is small, moving from the $25^{\text {th }}$ to $75^{\text {th }}$ percentile does not change the mean by more than 0.5 points, both in rural and urban areas.

We also find that

- $\quad$ Student-teacher ratio has a consistently negative effect but when disaggregating the sample into urban and rural schools, this effect is not significant.

- Evening schools perform substantially less well (10 or more points less), urban schools do better than rural schools (about 2 points more) and there are substantial oblast specific effects. While introducing extra explanatory variables does reduce the importance of oblast specific dummies, some sizeable effects do remain. For example, the average score in urban schools in Lviv is expected to be 7 points more than the average score of schools located in Crimea. For rural schools this difference is 3 points.

- $\quad$ Gymnasia and Lycea score 5 to 10 points higher than other school types.

- The gender composition matters with more boys among the test takers reducing the average school score. Going from the $25^{\text {th }}$ percentile to the $75^{\text {th }}$ percentile in terms of share of boys will decrease the average score by 1.5 to 2.5 points.

- The unemployment rate is never significant but a higher average wage goes together with a slight decrease in points. Schools in bigger (more populated) communities have slightly higher mean scores.

\footnotetext{
${ }^{29}$ In fact, given that on these topics a lower number of students participate, a lower number of schools have a participation ratio above 1 for these subjects resulting in samples that are slightly bigger than when looking at the Ukrainian test scores.
} 
- The language of choice has a substantial effect - moving from a school where about $40 \%$ of the exams are taken in a language other than Ukrainian $\left(25^{\text {th }}\right.$ percentile $)$ to a school where all students take all exams in Ukrainian $\left(75^{\text {th }}\right.$ percentile) increases the average score on the Ukrainian exam by about 4 points.

- Controlling for selection by including the participation ratio does not change the results much, even though the participation ratio has a positive and significant effect on the average score, especially for urban areas but also for rural areas. This suggests that better schools have higher grades and higher participation.

- $\quad$ Our explanatory variables explain about 40 percent of the variation in mean scores for rural schools, but substantially less (15 percent) for rural schools. 
Table 7 - Ukrainian Language, Mean Score

\begin{tabular}{|c|c|c|c|c|c|c|c|c|c|c|c|c|}
\hline & \multicolumn{4}{|c|}{ Total } & \multicolumn{4}{|c|}{ Urban } & \multicolumn{4}{|c|}{ Rural } \\
\hline & (1) & (2) Extended & (3) & (4) & (1) & (2) Extended & (3) & (4) & (1) & (2) Extended & (3) & (4) \\
\hline \multirow[t]{2}{*}{ \# students } & $0.009 * * *$ & $0.009 * * *$ & $0.011 * * *$ & $0.009 * * *$ & $0.009 * * *$ & $0.009 * * *$ & $0.016^{* * *}$ & $0.009 * * *$ & 0.002 & 0.001 & $0.013 * * *$ & $0.012 * * *$ \\
\hline & 19.21 & 18.5 & 7.9 & 6.46 & 16.83 & 17.05 & 9.41 & 5.6 & 1.18 & 0.86 & 2.98 & 2.7 \\
\hline \multirow[t]{2}{*}{$(\# \text { students) })^{2}$} & & & $-0.000 * *$ & 0 & & & $-0.000 * * *$ & $-0.000^{*}$ & & & $-0.000 * * *$ & $-0.000 * *$ \\
\hline & & & -2 & -0.96 & & & -4.72 & -1.76 & & & -2.76 & -2.56 \\
\hline \multirow[t]{2}{*}{ Student/Teacher } & $-0.183 * * *$ & $-0.178 * * *$ & $-0.318 * * *$ & $-0.364 * * *$ & -0.05 & -0.087 & -0.216 & $-0.298^{*}$ & -0.056 & -0.047 & -0.274 & -0.317 \\
\hline & -3.76 & -3.84 & -2.74 & -3.16 & -0.78 & -1.43 & -1.21 & -1.72 & -0.66 & -0.59 & -1.2 & -1.4 \\
\hline \multirow[t]{2}{*}{ (Stud./Teacher) ${ }^{2}$} & & & $0.007 *$ & $0.009 * *$ & & & 0.004 & 0.008 & & & 0.006 & 0.009 \\
\hline & & & 1.66 & 2.21 & & & 0.73 & 1.47 & & & 0.56 & 0.8 \\
\hline \multirow[t]{2}{*}{ Class Size } & $-0.081 * * *$ & $-0.068 * * *$ & $-0.347 * * *$ & $-0.351 * * *$ & -0.003 & 0.015 & $-0.443 * * *$ & $-0.413 * * *$ & $-0.052 * *$ & $-0.057 * *$ & -0.16 & $-0.183 *$ \\
\hline & -4.6 & -3.95 & -5.08 & -5.17 & -0.11 & 0.55 & -3.18 & -3.06 & -2.08 & -2.36 & -1.64 & -1.88 \\
\hline \multirow[t]{2}{*}{$(\text { Class Size })^{2}$} & & & $0.008 * * *$ & $0.008^{* * *}$ & & & $0.011 * * *$ & $0.010 * * *$ & & & 0.003 & 0.004 \\
\hline & & & 4.58 & 4.78 & & & 3.48 & 3.26 & & & 1.02 & 1.34 \\
\hline \multirow[t]{2}{*}{ Urban } & $1.714 * * *$ & $2.047 * * *$ & $2.059 * * *$ & $1.525 * * *$ & & & & & & & & \\
\hline & 6.55 & 7.99 & 7.57 & 5.68 & & & & & & & & \\
\hline \multirow[t]{2}{*}{ Gender Comp. } & & $-0.109 * * *$ & $-0.109 * * *$ & $-0.116^{* * *}$ & & $-0.114 * * *$ & $-0.115 * * *$ & $-0.122 * * *$ & & $-0.109 * * *$ & $-0.109 * * *$ & $-0.112 * * *$ \\
\hline & & -19.75 & -19.8 & -21.11 & & -10.69 & -10.82 & -12 & & -16.86 & -16.86 & -17.35 \\
\hline \multirow[t]{2}{*}{ Unemployment rate 2009} & & 0.029 & 0.023 & -0.018 & & 0.031 & 0.015 & -0.036 & & -0.032 & -0.024 & -0.044 \\
\hline & & 0.47 & 0.37 & -0.29 & & 0.3 & 0.14 & -0.36 & & -0.41 & -0.31 & -0.56 \\
\hline \multirow[t]{2}{*}{ Average Wage 2009} & & $-0.001 * * *$ & $-0.001 * * *$ & $-0.001 * * *$ & & $-0.001 * * *$ & $-0.001 * * *$ & $-0.002 * * *$ & & 0 & 0 & 0 \\
\hline & & -3.15 & -3.4 & -3.95 & & -3.64 & -3.71 & -3.94 & & 0.15 & 0.07 & -0.19 \\
\hline \multirow[t]{2}{*}{ Population } & & $0.009 * * *$ & $0.007 * * *$ & $0.007 * * *$ & & $0.007 * * *$ & $0.007 * * *$ & $0.006^{* * *}$ & & $0.122 * * *$ & $0.115^{* * *}$ & $0.105^{* * *}$ \\
\hline & & 4.83 & 4.2 & 4.01 & & 3.54 & 3.5 & 3.36 & & 8.35 & 7.88 & 7.07 \\
\hline \multirow[t]{2}{*}{ Share Ukrainian } & & $0.072 * * *$ & $0.072 * * *$ & $0.071 * * *$ & & $0.063 * * *$ & $0.064 * * *$ & $0.061 * * *$ & & $0.070 * * *$ & $0.070 * * *$ & $0.069 * * *$ \\
\hline & & 17.2 & 17.23 & 17.35 & & 10.47 & 10.56 & 10.49 & & 11.48 & 11.55 & 11.6 \\
\hline \multirow[t]{2}{*}{ Participation Ratio } & & & & $0.073 * * *$ & & & & $0.179 * * *$ & & & & $0.031 * * *$ \\
\hline & & & & 12.85 & & & & 15.15 & & & & 4.82 \\
\hline _cons & $154.054 * * *$ & $158.393 * * *$ & $160.926 * * *$ & $156.307 * * *$ & $153.541 * * *$ & $159.317 * * *$ & $163.011 * * *$ & $149.337 * * *$ & $148.706^{* * *}$ & $152.515^{* * *}$ & $152.942 * * *$ & $151.437 * * *$ \\
\hline
\end{tabular}




\begin{tabular}{|c|c|c|c|c|c|c|c|c|c|c|c|c|}
\hline & 233.99 & 198.02 & 161.95 & 146.12 & 158.55 & 126.84 & 84.79 & 69.49 & 87.01 & 86.29 & 77.44 & 76.05 \\
\hline R Adj sq. & 0.262 & 0.321 & 0.323 & 0.339 & 0.391 & 0.431 & 0.434 & 0.483 & 0.079 & 0.159 & 0.16 & 0.164 \\
\hline $\mathrm{N}$ & 10906 & 10906 & 10906 & 10906 & 4922 & 4922 & 4922 & 4922 & 5984 & 5984 & 5984 & 5984 \\
\hline
\end{tabular}

The regression also includes oblast dummies, dummies for different types of schools and evening schools. The full table can be found in excel tables which can be made available upon request. ** means significant at the $1 \%$ level, ** at the $5 \%$ level and $*$ at the 10 percent level.T statistics are based on robust standard errors for the OLS specifications. 
Next we compare the Ukrainian exam scores to the mathematics and the history scores (table 8a and $8 b)$.

- $\quad$ By and large, the results for the mathematics and history tests are similar to the results for the Ukrainian test. Bigger schools do get better average scores while schools with higher student-teacher ratios and higher class sizesget lower scores, though the latter effect is small and often not significant.

- Gender is much less important for math and history than for Ukrainian (for math even insignificant in urban areas). The fact that there is an effect of language choice on Ukrainian history and to a lesser extent on math outcomessuggest that those schools where students choose to take the exams in a language other than Ukrainian are somewhat weaker in general. Hence, the language effect we found in the Ukrainian language exam is likely to be an upper bound.

- The size of the community has a positive effect on the mean score. For urban schools, the average wage has a negative effect and for the math score unemployment has a positive effect.

- Controlling for selection does not change the general results, and has a small positive effect for urban schools and a small negative effect for rural schools.

- Given the smaller number of students on which the school means are based, it is not surprising that the part of the variation in scores that is explained by our explanatory variables is smaller than in the case of Ukrainian language. For the same reason, it is not surprising that we can explain more in the urban than in the rural regressions. 
Table 8a-Mathematics, Mean Score

\begin{tabular}{|c|c|c|c|c|c|c|c|c|c|c|c|c|}
\hline & \multicolumn{4}{|c|}{ Total } & \multicolumn{4}{|c|}{ Urban } & \multicolumn{4}{|c|}{ Rural } \\
\hline & (1) & (2) & (3) & (4) & (1) & (2) & (3) & (4) & (1) & (2) & (3) & (4) \\
\hline \multirow[t]{2}{*}{ \# students } & $0.010 * * *$ & $0.009 * * *$ & $0.011 * * *$ & $0.012 * * *$ & $0.010 * * *$ & $0.009 * * *$ & $0.016^{* * *}$ & $0.014 * * *$ & 0.003 & 0.002 & $0.014 * * *$ & $0.015 * * *$ \\
\hline & 19.11 & 17.56 & 7.36 & 7.39 & 17.78 & 16.89 & 9.18 & 8.24 & 1.48 & 0.97 & 2.69 & 2.82 \\
\hline \multirow[t]{2}{*}{ (\# students) $^{2}$} & & & $-0.000^{*}$ & $-0.000 *$ & & & $-0.000 * * *$ & $-0.000^{* * *}$ & & & $-0.000^{* * *}$ & $-0.000 * * *$ \\
\hline & & & -1.84 & -1.87 & & & -4.46 & -3.77 & & & -2.62 & -2.72 \\
\hline \multirow[t]{2}{*}{ Student/Teacher } & $-0.219 * * *$ & $-0.194 * * *$ & $-0.419^{* * *}$ & $-0.417 * * *$ & $-0.136^{* *}$ & $-0.129 * *$ & $-0.503 * *$ & $-0.550 * * *$ & -0.057 & -0.039 & -0.048 & 0.002 \\
\hline & -4.23 & -3.78 & -2.9 & -2.88 & -2.09 & -2 & -2.4 & -2.65 & -0.59 & -0.4 & -0.18 & 0.01 \\
\hline \multirow[t]{2}{*}{ (Stud./Teacher) ${ }^{2}$} & & & $0.010^{*}$ & $0.010^{*}$ & & & $0.014 *$ & $0.015^{* *}$ & & & -0.008 & -0.01 \\
\hline & & & 1.85 & 1.84 & & & 1.8 & 2.07 & & & -0.62 & -0.81 \\
\hline \multirow[t]{2}{*}{ Class Size } & -0.031 & $-0.036^{*}$ & $-0.216^{* * *}$ & $-0.220 * * *$ & $0.052 *$ & 0.038 & -0.193 & -0.145 & -0.034 & -0.039 & -0.08 & -0.117 \\
\hline & -1.56 & -1.83 & -2.71 & -2.75 & 1.93 & 1.35 & -1.32 & -0.99 & -1.13 & -1.32 & -0.68 & -0.99 \\
\hline \multirow[t]{2}{*}{$(\text { Class Size })^{2}$} & & & $0.005^{* * *}$ & $0.005^{* * *}$ & & & $0.005^{*}$ & 0.004 & & & 0.001 & 0.001 \\
\hline & & & 2.59 & 2.62 & & & 1.68 & 1.34 & & & 0.22 & 0.38 \\
\hline \multirow[t]{2}{*}{ Urban } & $2.170 * * *$ & $1.841^{* * *}$ & $1.826 * * *$ & $1.841 * * *$ & & & & & & & & \\
\hline & 7.81 & 6.48 & 6.04 & 6.07 & & & & & & & & \\
\hline \multirow[t]{2}{*}{ Gender Comp. } & & $-0.022 * * *$ & $-0.022 * * *$ & $-0.022 * * *$ & & -0.009 & -0.009 & -0.009 & & $-0.026^{* * *}$ & $-0.027 * * *$ & $-0.027 * * *$ \\
\hline & & -4.36 & -4.35 & -4.36 & & -0.98 & -1.02 & -0.94 & & -4.41 & -4.42 & -4.48 \\
\hline \multirow[t]{2}{*}{$\begin{array}{l}\text { Unemployment } \\
\text { rate } 2009\end{array}$} & & $0.140^{*}$ & $0.136^{*}$ & $0.136^{*}$ & & $0.220^{* *}$ & $0.197 *$ & $0.180^{*}$ & & 0.048 & 0.06 & 0.064 \\
\hline & & 1.93 & 1.87 & 1.88 & & 2.04 & 1.82 & 1.66 & & 0.5 & 0.63 & 0.67 \\
\hline \multirow[t]{2}{*}{$\begin{array}{c}\text { Average Wage } \\
2009 \\
\end{array}$} & & $-0.001 * *$ & $-0.001 * *$ & $-0.001 * *$ & & $-0.001^{*}$ & $-0.001 *$ & $-0.001 * *$ & & 0 & 0 & 0 \\
\hline & & -2.1 & -2.26 & -2.19 & & -1.78 & -1.82 & -2.5 & & -0.71 & -0.76 & -0.27 \\
\hline \multirow[t]{2}{*}{ Population } & & $0.013 * * *$ & $0.012^{* * *}$ & $0.012 * * *$ & & $0.011 * * *$ & $0.011 * * *$ & $0.011^{* * *}$ & & $0.136^{* * *}$ & $0.131^{* * *}$ & $0.149^{* * *}$ \\
\hline & & 6.63 & 6.21 & 6.21 & & 5.54 & 5.57 & 5.61 & & 7.28 & 7.06 & 7.92 \\
\hline \multirow[t]{2}{*}{ Share Ukrainian } & & $0.017 * * *$ & $0.018 * * *$ & $0.018^{* * *}$ & & 0.01 & $0.011^{*}$ & $0.012^{*}$ & & $0.014^{*}$ & $0.014 * *$ & $0.014^{*}$ \\
\hline & & 3.75 & 3.82 & 3.81 & & 1.63 & 1.76 & 1.86 & & 1.96 & 2.02 & 1.94 \\
\hline $\begin{array}{l}\text { Participation } \\
\text { Ratio }\end{array}$ & & & & -0.004 & & & & $0.064 * * *$ & & & & $-0.044 * * *$ \\
\hline
\end{tabular}




\begin{tabular}{|c|c|c|c|c|c|c|c|c|c|c|c|c|}
\hline & & & & -0.64 & & & & 7.23 & & & & -5.91 \\
\hline cons & $156.080^{* * *}$ & $157.799 * * *$ & $159.920 * * *$ & $160.072 * * *$ & $156.375^{* * *}$ & $157.339 * * *$ & $160.144 * * *$ & $157.525 * * *$ & $149.958 * * *$ & $151.608^{* * *}$ & $150.735^{* * *}$ & $152.247 * * *$ \\
\hline & 212.26 & 169.96 & 135.99 & 131.1 & 145.86 & 115.15 & 75.85 & 72.14 & 72.02 & 67.68 & 60.41 & 60.94 \\
\hline R Adj sq. & 0.196 & 0.202 & 0.203 & 0.203 & 0.303 & 0.307 & 0.309 & 0.319 & 0.026 & 0.032 & 0.033 & 0.039 \\
\hline $\mathrm{N}$ & 10961 & 10961 & 10961 & 10961 & 5143 & 5143 & 5143 & 5143 & 5818 & 5818 & 5818 & 5818 \\
\hline
\end{tabular}

The regression also includes oblast dummies, dummies for different types of schools and evening schools. The full table can be found in excel tables which can be made available upon request. *** means significant at the $1 \%$ level, ** at the $5 \%$ level and * at the 10 percent level.T statistics are based on robust standard errors for the OLS specifications.

Table 8b-Ukrainian History, Mean Score

\begin{tabular}{|c|c|c|c|c|c|c|c|c|c|c|c|c|}
\hline & \multicolumn{4}{|c|}{ Total } & \multicolumn{4}{|c|}{ Urban } & \multicolumn{4}{|c|}{ Rural } \\
\hline & (1) & (2) & (3) & (4) & (1) & (2) & (3) & (4) & (1) & (2) & (3) & (4) \\
\hline \multirow[t]{2}{*}{$\#$ students } & $0.006 * * *$ & $0.005 * * *$ & $0.006 * * *$ & $0.006 * * *$ & $0.005 * * *$ & $0.005 * * *$ & $0.008 * * *$ & $0.007 * * *$ & 0.001 & 0.001 & $0.012 * * *$ & $0.013 * * *$ \\
\hline & 12.67 & 11.97 & 4.28 & 4.3 & 10.76 & 10.59 & 5.02 & 4.53 & 0.95 & 0.79 & 2.73 & 2.9 \\
\hline \multirow[t]{2}{*}{ (\# students) $^{2}$} & & & 0 & 0 & & & $-0.000^{*}$ & 0 & & & $-0.000 * * *$ & $-0.000 * * *$ \\
\hline & & & -0.43 & -0.46 & & & -1.86 & -1.48 & & & -2.82 & -2.95 \\
\hline \multirow[t]{2}{*}{ Student/Teacher } & $-0.224 * * *$ & $-0.208 * * *$ & $-0.288^{* *}$ & $-0.287^{* *}$ & $-0.130 * *$ & $-0.145^{* *}$ & $-0.333 *$ & $-0.340^{*}$ & -0.09 & -0.082 & -0.178 & -0.16 \\
\hline & -4.83 & -4.54 & -2.3 & -2.29 & -2.24 & -2.54 & -1.9 & -1.93 & -1.05 & -0.97 & -0.76 & -0.68 \\
\hline \multirow[t]{2}{*}{$(\text { Stud./Teacher) })^{2}$} & & & 0.005 & 0.005 & & & 0.008 & 0.009 & & & 0 & -0.001 \\
\hline & & & 1.14 & 1.13 & & & 1.31 & 1.35 & & & 0.02 & -0.1 \\
\hline \multirow[t]{2}{*}{ Class Size } & $-0.095 * * *$ & $-0.082 * * *$ & $-0.410 * * *$ & $-0.410 * * *$ & -0.031 & -0.016 & $-0.452 * * *$ & $-0.446 * * *$ & $-0.083 * * *$ & $-0.086^{* * *}$ & $-0.332 * * *$ & $-0.333 * * *$ \\
\hline & -5.34 & -4.6 & -5.51 & -5.5 & -1.29 & -0.64 & -3.18 & -3.15 & -3.07 & -3.19 & -3.08 & -3.08 \\
\hline \multirow[t]{2}{*}{$(\text { Class Size })^{2}$} & & & $0.009 * * *$ & $0.009 * * *$ & & & $0.011^{* * *}$ & $0.010^{* * *}$ & & & $0.007 * *$ & $0.007 * *$ \\
\hline & & & 5.16 & 5.16 & & & 3.4 & 3.37 & & & 2.47 & 2.44 \\
\hline \multirow[t]{2}{*}{ Urban } & $1.641 * * *$ & $1.847 * * *$ & $1.983 * * *$ & $1.994 * * *$ & & & & & & & & \\
\hline & 6.65 & 7.35 & 7.4 & 7.37 & & & & & & & & \\
\hline \multirow[t]{2}{*}{ Gender Comp. } & & $-0.017 * * *$ & $-0.017 * * *$ & $-0.017 * * *$ & & $-0.029 * * *$ & $-0.030 * * *$ & $-0.032 * * *$ & & $-0.014 * *$ & $-0.014 * *$ & $-0.012 *$ \\
\hline & & -3.09 & -3.12 & -3.06 & & -3.01 & -3.09 & -3.29 & & -2.02 & -2.02 & -1.82 \\
\hline Unemployment rate 2009 & & 0.034 & 0.028 & 0.029 & & -0.031 & -0.026 & -0.027 & & 0.011 & 0.013 & 0.024 \\
\hline
\end{tabular}




\begin{tabular}{|c|c|c|c|c|c|c|c|c|c|c|c|c|}
\hline & & 0.49 & 0.42 & 0.43 & & -0.31 & -0.26 & -0.27 & & 0.12 & 0.14 & 0.27 \\
\hline \multirow[t]{2}{*}{ Average Wage 2009} & & $-0.001 * * *$ & $-0.001 * * *$ & $-0.001 * * *$ & & $-0.001 * * *$ & $-0.002 * * *$ & $-0.001 * * *$ & & -0.001 & -0.001 & -0.001 \\
\hline & & -3.72 & -4.01 & -4.01 & & -4.04 & -4.19 & -4.06 & & -1.06 & -1.14 & -1.09 \\
\hline \multirow[t]{2}{*}{ Population } & & $0.007 * * *$ & $0.005^{* * *}$ & $0.005^{* * *}$ & & $0.005^{* * *}$ & $0.005^{* * *}$ & $0.004 * *$ & & $0.091 * * *$ & $0.079 * * *$ & $0.081 * * *$ \\
\hline & & 4.03 & 3.04 & 3.06 & & 2.95 & 2.65 & 2.49 & & 5.38 & 4.48 & 4.74 \\
\hline \multirow[t]{2}{*}{ Share Ukrainian } & & $0.052 * * *$ & $0.052 * * *$ & $0.052 * * *$ & & $0.046^{* * *}$ & $0.046^{* * *}$ & $0.046^{* * *}$ & & $0.047 * * *$ & $0.047 * * *$ & $0.047 * * *$ \\
\hline & & 12.41 & 12.39 & 12.39 & & 8.34 & 8.35 & 8.33 & & 7.01 & 7.06 & 7.1 \\
\hline \multirow[t]{2}{*}{ Participation Ratio } & & & & -0.002 & & & & $0.022 * *$ & & & & $-0.015^{* *}$ \\
\hline & & & & -0.33 & & & & 2.52 & & & & -2.07 \\
\hline \multirow[t]{2}{*}{ _cons } & $154.661 * * *$ & $155.621 * * *$ & $158.498 * * *$ & $158.593 * * *$ & $155.297 * * *$ & $157.593 * * *$ & $162.157 * * *$ & $160.874 * * *$ & $149.420 * * *$ & $150.028 * * *$ & $151.062 * * *$ & $151.739 * * *$ \\
\hline & 246.41 & 197.65 & 154.34 & 144.47 & 173.78 & 140.19 & 87.32 & 81.47 & 101.52 & 93.1 & 81.19 & 79.35 \\
\hline R Adj sq. & 0.153 & 0.169 & 0.171 & 0.171 & 0.295 & 0.311 & 0.314 & 0.316 & 0.046 & 0.055 & 0.056 & 0.057 \\
\hline $\mathrm{N}$ & 11086 & 11086 & 11086 & 11086 & 5137 & 5137 & 5137 & 5137 & 5949 & 5949 & 5949 & 5949 \\
\hline
\end{tabular}

The regression also includes oblast dummies, dummies for different types of schools and evening schools. The full table can be found in excel tables which can be made available upon request. $* * *$ means significant at the $1 \%$ level, $* *$ at the $5 \%$ level and $*$ at the 10 percent level.T statistics are based on robust standard errors for the OLS specifications. 
From the EIT center, we also obtained school averages disaggregated by gender. Note that, based on descriptive statistics, girls do better than boys, on average, on all subjects, except for Geography, with the gender gap to be most substantial on the Ukrainian exam.

When running regressions by gender, we use the average score of the female students, respectively male students, of a school and regress it on the same set of explanatory variables, with the exception that our language variable is now the percentage of exams (other than the Ukrainian exam) taken in Ukrainian by the female students of a school rather than by all students.

We find that for the Ukrainian exam (table 9a and 9b)

- Like for the total sample, school size has a positive effect on the school's mean Ukrainian exam score for both males and female students. Again, the effect is clearly stronger for urban schools.

- Class size has a negative effect for male and female students and this effect is statistically significant for male students and almost significant for female students. The size of these effects is bigger for males than for females but in both cases moving from the $25^{\text {th }}$ to $75^{\text {th }}$ percentile does not change the mean by more than 1 point.

We also find that

- Student-teacher ratio has a consistently negative effect but like for the whole sample, for females when dis-aggregating the sample into urban and rural schools, this effect is not significant. For boys there is a significant negative non-linear effect, but the size of this effect is very small.

- $\quad$ Evening schools perform substantially less well (more so for girls than for boys), urban schools do better than rural schools and there are substantial oblast specific effects.

- Gymnasia and Lycea score 5 to 10 points higher than other school types.

- The gender composition matters little for girls but is significant for boys: more boys among the test takers reduces the average school scores of boys somewhat: going from the $25^{\text {th }}$ percentile to the $75^{\text {th }}$ percentile in terms of share of boys will decrease the average score by 0.3 to 0.6 points. The fact that we found a negative effect of the share of 
boys on the school score when using the total school average (girls and boys combined) is thus mainly due to the fact that girls on average score better, but not (or only marginally so) because mixed gender classes have a negative effect on class performance.

- The unemployment rate is never significant but a higher average wage goes together with a slight decrease in points. Schools in bigger (more populated) communities have slightly higher mean scores. This was true for the total school average but also for the male and female average.

- Both for female and male students, the language of choice has a substantial effect on the average grade, with the more students take exams in Ukrainian the better the average Ukrainian score

- $\quad$ Like before, both for males and females the participation ratio has a positive and significant effect on the average score in urban areas. For rural areas, the effect is smaller and only significant for females. This suggests that better schools have higher grades and higher participation, except for male students in rural schools.

- Our explanatory variables explain more of the variation in mean scores for urban schools, and less for rural schools, and more for girls than for boys.

Results for the mathematics and the Ukrainian history exam are broadly similar to what we found so far. It is worth to note however that for males, there is no effect of language choice on math achievement however. 
Table 9a - Female Students, Ukrainian

\begin{tabular}{|c|c|c|c|c|c|c|c|c|c|c|c|c|}
\hline & \multicolumn{4}{|c|}{ Total } & \multicolumn{4}{|c|}{ Urban } & \multicolumn{4}{|c|}{ Rural } \\
\hline & (1) & (2) & (3) & (4) & (1) & (2) & (3) & (4) & (1) & (2) & (3) & (4) \\
\hline \multirow[t]{2}{*}{ \# students } & $0.009 * * *$ & $0.009 * * *$ & $0.012 * * *$ & $0.009 * * *$ & $0.009 * * *$ & $0.009 * * *$ & $0.015 * * *$ & $0.009 * * *$ & 0.003 & 0.003 & $0.020 * * *$ & $0.017 * * *$ \\
\hline & 16.8 & 16.11 & 7.17 & 5.6 & 14.96 & 15.03 & 8.09 & 4.77 & 1.54 & 1.41 & 3.67 & 3.29 \\
\hline \multirow[t]{2}{*}{ (\# students) $^{2}$} & & & $-0.000 * *$ & 0 & & & $-0.000 * * *$ & 0 & & & $-0.000 * * *$ & $-0.000 * * *$ \\
\hline & & & -2.3 & -1.21 & & & -4.11 & -1.63 & & & -3.38 & -3.12 \\
\hline \multirow[t]{2}{*}{ Student/Teacher } & $-0.190 * * *$ & $-0.171 * * *$ & -0.122 & -0.187 & -0.082 & -0.107 & 0.007 & -0.079 & -0.036 & -0.033 & -0.3 & -0.382 \\
\hline & -3.44 & -3.15 & -0.83 & -1.28 & -1.15 & -1.53 & 0.03 & -0.37 & -0.36 & -0.33 & -1 & -1.32 \\
\hline \multirow[t]{2}{*}{ (Stud./Teacher) $^{2}$} & & & -0.003 & 0.001 & & & -0.006 & -0.002 & & & 0.006 & 0.011 \\
\hline & & & -0.44 & 0.1 & & & -0.77 & -0.26 & & & 0.37 & 0.72 \\
\hline \multirow[t]{2}{*}{ Class Size } & $-0.073 * * *$ & $-0.053 * * *$ & $-0.325 * * *$ & $-0.279 * * *$ & 0.003 & 0.033 & $-0.292 *$ & -0.211 & -0.049 & $-0.052^{*}$ & -0.191 & -0.188 \\
\hline & -3.61 & -2.64 & -3.84 & -3.32 & 0.11 & 1.12 & -1.7 & -1.25 & -1.64 & -1.75 & -1.57 & -1.56 \\
\hline \multirow[t]{2}{*}{$(\text { Class Size })^{2}$} & & & $0.007 * * *$ & $0.006^{* * *}$ & & & $0.007 *$ & 0.005 & & & 0.004 & 0.004 \\
\hline & & & 3.52 & 3.14 & & & 1.94 & 1.42 & & & 1.09 & 1.23 \\
\hline \multirow[t]{2}{*}{ Urban } & $1.724 * * *$ & $2.018 * * *$ & $1.926 * * *$ & $1.232 * * *$ & & & & & & & & \\
\hline & 5.8 & 6.82 & 6.07 & 3.9 & & & & & & & & \\
\hline \multirow[t]{2}{*}{ Gender Comp. } & & 0.003 & 0.004 & $-0.013^{*}$ & & -0.007 & -0.007 & $-0.023^{*}$ & & 0.004 & 0.005 & -0.007 \\
\hline & & 0.35 & 0.58 & -1.83 & & -0.56 & -0.5 & -1.84 & & 0.52 & 0.57 & -0.82 \\
\hline \multirow[t]{2}{*}{$\begin{array}{l}\text { Unemployment } \\
\text { rate } 2009\end{array}$} & & 0.122 & 0.12 & 0.074 & & 0.049 & 0.031 & -0.018 & & 0.093 & 0.106 & 0.077 \\
\hline & & 1.62 & 1.59 & 1 & & 0.43 & 0.27 & -0.16 & & 0.94 & 1.06 & 0.79 \\
\hline \multirow[t]{2}{*}{$\begin{array}{c}\text { Average Wage } \\
2009 \\
\end{array}$} & & $-0.001 * * *$ & $-0.001 * * *$ & $-0.001 * * *$ & & $-0.002 * * *$ & $-0.002 * * *$ & $-0.002 * * *$ & & 0 & 0 & 0 \\
\hline & & -3.48 & -3.62 & -4.18 & & -4.38 & -4.38 & -4.6 & & 0.24 & 0.15 & -0.2 \\
\hline \multirow[t]{2}{*}{ Population } & & $0.008^{* * *}$ & $0.007 * * *$ & $0.007 * * *$ & & $0.007 * * *$ & $0.007 * * *$ & $0.006^{* * *}$ & & $0.114 * * *$ & $0.105 * * *$ & $0.089 * * *$ \\
\hline & & 4.04 & 3.7 & 3.5 & & 3.06 & 3.19 & 3.05 & & 6.69 & 6.25 & 5.16 \\
\hline \multirow[t]{2}{*}{ Share Ukrainian } & & $7.291 * * *$ & $7.302 * * *$ & $7.158 * * *$ & & $7.507 * * *$ & $7.500 * * *$ & $7.330 * * *$ & & $6.057 * * *$ & $6.112 * * *$ & $6.015^{* * *}$ \\
\hline & & 15.1 & 15.11 & 15.12 & & 11.57 & 11.63 & 11.7 & & 8.11 & 8.19 & 8.15 \\
\hline
\end{tabular}




\begin{tabular}{|c|c|c|c|c|c|c|c|c|c|c|c|c|}
\hline $\begin{array}{l}\text { Participation } \\
\text { Ratio }\end{array}$ & & & & $0.091 * * *$ & & & & $0.174 * * *$ & & & & $0.055 * * *$ \\
\hline & & & & 13.05 & & & & 11.98 & & & & 6.82 \\
\hline _cons & $157.635^{* * *}$ & $157.246^{* * *}$ & $158.781 * * *$ & $152.888^{* * *}$ & $157.263 * * *$ & $158.611 * * *$ & $159.879 * * *$ & $146.369 * * *$ & $154.198 * * *$ & $152.828 * * *$ & $153.189 * * *$ & $150.478 * * *$ \\
\hline & 217.36 & 173.75 & 136.42 & 121.88 & 144.11 & 115.96 & 71.21 & 57.63 & 85.21 & 80.1 & 69.16 & 67.23 \\
\hline R Adj sq. & 0.218 & 0.239 & 0.24 & 0.258 & 0.355 & 0.38 & 0.382 & 0.422 & 0.075 & 0.088 & 0.089 & 0.098 \\
\hline $\mathrm{N}$ & 10730 & 10723 & 10723 & 10723 & 4890 & 4886 & 4886 & 4886 & 5840 & 5837 & 5837 & 5837 \\
\hline
\end{tabular}

The regression also includes oblast dummies, dummies for different types of schools and evening schools. The full table can be found in excel tables which can be made available upon request. *** means significant at the $1 \%$ level, ** at the $5 \%$ level and * at the 10 percent level.T statistics are based on robust standard errors for the OLS specifications.

Table $9 b$ - Male Students, Ukrainian

\begin{tabular}{|c|c|c|c|c|c|c|c|c|c|c|c|c|}
\hline & \multicolumn{4}{|c|}{ Total } & \multicolumn{4}{|c|}{ Urban } & \multicolumn{4}{|c|}{ Rural } \\
\hline & (1) & (2) & (3) & (4) & (1) & (2) & (3) & (4) & (1) & (2) & (3) & (4) \\
\hline \multirow[t]{2}{*}{ \# students } & $0.010 * * *$ & $0.009 * * *$ & $0.010 * * *$ & $0.009 * * *$ & $0.009 * * *$ & $0.009 * * *$ & $0.016^{* * *}$ & $0.009 * * *$ & 0 & 0 & $0.009 *$ & $0.010^{*}$ \\
\hline & 17.25 & 16.22 & 6.09 & 5.38 & 15.34 & 14.99 & 7.9 & 4.88 & 0.04 & -0.02 & 1.65 & 1.73 \\
\hline \multirow[t]{2}{*}{ (\# students) $^{2}$} & & & 0 & 0 & & & $-0.000 * * *$ & 0 & & & $-0.000^{*}$ & $-0.000^{*}$ \\
\hline & & & -0.78 & -0.27 & & & -3.63 & -1.3 & & & -1.77 & -1.83 \\
\hline \multirow[t]{2}{*}{ Student/Teacher } & $-0.201 * * *$ & $-0.206 * * *$ & $-0.479 * * *$ & $-0.503 * * *$ & -0.048 & -0.076 & $-0.381^{*}$ & $-0.469 * *$ & -0.036 & -0.071 & -0.178 & -0.164 \\
\hline & -3.42 & -3.53 & -3.18 & -3.34 & -0.66 & -1.04 & -1.78 & -2.24 & -0.34 & -0.68 & -0.57 & -0.53 \\
\hline \multirow[t]{2}{*}{ (Stud./Teacher) $)^{2}$} & & & $0.014 * * *$ & $0.016^{* * *}$ & & & $0.012 *$ & $0.016^{* *}$ & & & 0.001 & 0 \\
\hline & & & 2.6 & 2.8 & & & 1.69 & 2.3 & & & 0.07 & 0.01 \\
\hline \multirow[t]{2}{*}{ Class Size } & $-0.100 * * *$ & $-0.101 * * *$ & $-0.487 * * *$ & $-0.460 * * *$ & 0.005 & 0.004 & $-0.602 * * *$ & $-0.552 * * *$ & $-0.084 * *$ & $-0.097 * * *$ & $-0.247 *$ & $-0.250^{*}$ \\
\hline & -4.55 & -4.52 & -5.53 & -5.22 & 0.16 & 0.11 & -3.54 & -3.3 & -2.57 & -2.98 & -1.92 & -1.94 \\
\hline \multirow[t]{2}{*}{$(\text { Class Size })^{2}$} & & & $0.011 * * *$ & $0.010 * * *$ & & & $0.014 * * *$ & $0.013 * * *$ & & & 0.004 & 0.004 \\
\hline & & & 5.03 & 4.81 & & & 3.86 & 3.57 & & & 1.18 & 1.17 \\
\hline \multirow[t]{2}{*}{ Urban } & $2.099 * * *$ & $2.256^{* * *}$ & $2.424 * * *$ & $2.087 * * *$ & & & & & & & & \\
\hline & 6.64 & 7.02 & 7.11 & 6.1 & & & & & & & & \\
\hline \multirow[t]{2}{*}{ Gender Comp. } & & $-0.024 * * *$ & $-0.028 * * *$ & $-0.025 * * *$ & & $-0.038^{* * *}$ & $-0.041 * * *$ & $-0.040 * * *$ & & $-0.021 * *$ & $-0.021 * *$ & $-0.022 * *$ \\
\hline & & -3.04 & -3.57 & -3.26 & & -2.95 & -3.15 & -3.12 & & -2.17 & -2.24 & -2.32 \\
\hline $\begin{array}{c}\text { Unemployment } \\
\text { rate } 2009\end{array}$ & & -0.054 & -0.064 & -0.084 & & 0.023 & 0.018 & -0.028 & & -0.163 & -0.159 & -0.153 \\
\hline
\end{tabular}




\begin{tabular}{|c|c|c|c|c|c|c|c|c|c|c|c|c|}
\hline & & -0.67 & -0.79 & -1.04 & & 0.18 & 0.14 & -0.23 & & -1.57 & -1.52 & -1.47 \\
\hline \multirow[t]{2}{*}{$\begin{array}{c}\text { Average Wage } \\
2009 \\
\end{array}$} & & $-0.001 * *$ & $-0.001 * *$ & $-0.001 * * *$ & & $-0.001^{*}$ & $-0.001 * *$ & $-0.001 * *$ & & 0 & 0 & 0 \\
\hline & & -2.08 & -2.36 & -2.63 & & -1.87 & -1.97 & -2.15 & & -0.5 & -0.55 & -0.47 \\
\hline \multirow[t]{2}{*}{ Population } & & $0.009 * * *$ & $0.006^{* * *}$ & $0.006^{* * *}$ & & $0.006^{* *}$ & $0.005^{* *}$ & $0.005^{* *}$ & & $0.126^{* * *}$ & $0.119^{* * *}$ & $0.123 * * *$ \\
\hline & & 3.56 & 2.76 & 2.66 & & 2.25 & 2.1 & 1.98 & & 6.78 & 6.3 & 6.35 \\
\hline \multirow[t]{2}{*}{ Share Ukrainian } & & $6.568 * * *$ & $6.579 * * *$ & $6.518 * * *$ & & $4.626^{* * *}$ & $4.722 * * *$ & $4.614 * * *$ & & $7.418^{* * *}$ & $7.448 * * *$ & $7.465 * * *$ \\
\hline & & 12.88 & 12.88 & 12.85 & & 6.83 & 6.97 & 6.9 & & 9.49 & 9.51 & 9.52 \\
\hline \multirow[t]{2}{*}{$\begin{array}{c}\text { Participation } \\
\text { Ratio } \\
\end{array}$} & & & & $0.046^{* * *}$ & & & & $0.180 * * *$ & & & & -0.012 \\
\hline & & & & 6.25 & & & & 12.71 & & & & -1.39 \\
\hline \multirow[t]{2}{*}{ _cons } & $148.970 * * *$ & $150.224 * * *$ & $154.541 * * *$ & $151.036^{* * *}$ & $148.271 * * *$ & $150.637 * * *$ & $156.805^{* * *}$ & $142.434 * * *$ & $141.009 * * *$ & $141.960 * * *$ & $142.554 * * *$ & $143.334 * * *$ \\
\hline & 183.11 & 139.74 & 113.34 & 101.81 & 131.2 & 98.1 & 65.05 & 53.01 & 63.84 & 59.46 & 52.72 & 51.8 \\
\hline R Adj sq. & 0.195 & 0.211 & 0.214 & 0.218 & 0.321 & 0.333 & 0.337 & 0.376 & 0.038 & 0.056 & 0.056 & 0.057 \\
\hline $\mathrm{N}$ & 10503 & 10485 & 10485 & 10485 & 4876 & 4873 & 4873 & 4873 & 5627 & 5612 & 5612 & 5612 \\
\hline
\end{tabular}

The regression also includes oblast dummies, dummies for different types of schools and evening schools. The full table can be found in excel tables which can be made available upon request. *** means significant at the $1 \%$ level, ** at the $5 \%$ level and * at the 10 percent level.T statistics are based on robust standard errors for the OLS specifications. 
So far we have focused on the mean score. However, we also have data on the percentage of students in different parts of the distribution. We therefor run regressions with the percentage of students scoring above 173 and the percentage of students scoring below 135.5 (table 10a and $10 b)$.

Overall, the results confirm the findings we made so far (even though, as expected, the signs switch for the regression where we use the bottom students). One exception is that the studentteacher ratio now has, for urban schools, a consistently negative effect on the percentage of students above 173. Given the low variation in that ratio, however, going from the $25^{\text {th }}$ percentile to the $75^{\text {th }}$ percentile, does not change the percentage of top scoring students by more than 1 percentage point. 
Table 10a - Top Students, Ukrainian

\begin{tabular}{|c|c|c|c|c|c|c|c|c|c|c|c|c|}
\hline & \multicolumn{4}{|c|}{ Total } & \multicolumn{4}{|c|}{ Urban } & \multicolumn{4}{|c|}{ Rural } \\
\hline & (1) & (2) & (3) & (4) & (1) & (2) & (3) & (4) & (1) & (2) & (3) & (4) \\
\hline \multirow[t]{2}{*}{ \# students } & $0.012 * * *$ & $0.011 * * *$ & $0.011 * * *$ & $0.008 * * *$ & $0.011 * * *$ & $0.011 * * *$ & $0.014 * * *$ & $0.007 * *$ & $0.007 * * *$ & $0.006^{* * *}$ & $0.021^{* * *}$ & $0.019 * * *$ \\
\hline & 15.36 & 14.4 & 5.15 & 3.89 & 12.83 & 12.42 & 5.29 & 2.55 & 3.44 & 2.87 & 3.68 & 3.31 \\
\hline \multirow[t]{2}{*}{ (\# students) $^{2}$} & & & 0 & 0 & & & 0 & 0 & & & $-0.000 * * *$ & $-0.000 * *$ \\
\hline & & & -0.23 & 0.59 & & & -1.33 & 0.65 & & & -2.88 & -2.57 \\
\hline \multirow[t]{2}{*}{ Student/Teacher } & $-0.303 * * *$ & $-0.290 * * *$ & $-0.317 *$ & $-0.375 * *$ & $-0.241 * *$ & $-0.276 * * *$ & $-0.683 * *$ & $-0.771 * * *$ & -0.048 & -0.03 & -0.218 & -0.288 \\
\hline & -4.38 & -4.26 & -1.85 & -2.2 & -2.52 & -2.92 & -2.55 & -2.9 & -0.44 & -0.28 & -0.75 & -0.99 \\
\hline \multirow[t]{2}{*}{ (Stud./Teacher) $^{2}$} & & & 0.003 & 0.006 & & & $0.017^{* *}$ & $0.022 * *$ & & & 0.002 & 0.006 \\
\hline & & & 0.53 & 1 & & & 2.03 & 2.53 & & & 0.17 & 0.5 \\
\hline \multirow[t]{2}{*}{ Class Size } & $-0.051^{*}$ & $-0.045^{*}$ & $-0.418 * * *$ & $-0.423 * * *$ & 0.045 & 0.044 & $-0.590 * *$ & $-0.557^{* *}$ & -0.038 & -0.045 & -0.189 & -0.227 \\
\hline & -1.94 & -1.69 & -3.92 & -3.98 & 1.03 & 0.95 & -2.2 & -2.09 & -1.06 & -1.28 & -1.36 & -1.64 \\
\hline \multirow[t]{2}{*}{$(\text { Class Size })^{2}$} & & & $0.011^{* * *}$ & $0.011^{* * *}$ & & & $0.015^{* * *}$ & $0.014^{* *}$ & & & 0.004 & 0.005 \\
\hline & & & 3.96 & 4.1 & & & 2.64 & 2.46 & & & 1.02 & 1.4 \\
\hline \multirow[t]{2}{*}{ Urban } & $3.691 * * *$ & $3.745^{* * *}$ & $3.884 * * *$ & $3.212^{* * *}$ & & & & & & & & \\
\hline & 9.53 & 9.85 & 9.61 & 7.99 & & & & & & & & \\
\hline \multirow[t]{2}{*}{ Gender Comp. } & & $-0.094 * * *$ & $-0.094 * * *$ & $-0.102 * * *$ & & $-0.131 * * *$ & $-0.133 * * *$ & $-0.141 * * *$ & & $-0.084 * * *$ & $-0.084 * * *$ & $-0.090 * * *$ \\
\hline & & -11.9 & -11.89 & -13.16 & & -8.21 & -8.29 & -8.91 & & -9.24 & -9.24 & -10.04 \\
\hline \multirow[t]{2}{*}{$\begin{array}{c}\text { Unemployment } \\
\text { rate } 2009\end{array}$} & & 0.017 & 0.011 & -0.04 & & -0.095 & -0.09 & -0.145 & & -0.013 & -0.003 & -0.035 \\
\hline & & 0.19 & 0.12 & -0.45 & & -0.6 & -0.57 & -0.93 & & -0.11 & -0.02 & -0.31 \\
\hline \multirow[t]{2}{*}{$\begin{array}{c}\text { Average Wage } \\
2009 \\
\end{array}$} & & $-0.001 * * *$ & $-0.001 * * *$ & $-0.002 * * *$ & & $-0.001 * *$ & $-0.001 * *$ & $-0.001 * *$ & & -0.001 & -0.001 & $-0.001^{*}$ \\
\hline & & -3.27 & -3.48 & -3.97 & & -2.12 & -2.26 & -2.36 & & -1.32 & -1.38 & -1.71 \\
\hline \multirow[t]{2}{*}{ Population } & & $0.013 * * *$ & $0.012 * * *$ & $0.011 * * *$ & & $0.012 * * *$ & $0.011^{* * *}$ & $0.010^{* * *}$ & & $0.179 * * *$ & $0.171^{* * *}$ & $0.154 * * *$ \\
\hline & & 4.49 & 3.96 & 3.79 & & 3.54 & 3.34 & 3.24 & & 7.11 & 6.39 & 5 \\
\hline \multirow[t]{2}{*}{ Share Ukrainian } & & $0.058^{* * *}$ & $0.058 * * *$ & $0.056^{* * *}$ & & $0.060 * * *$ & $0.061 * * *$ & $0.058 * * *$ & & $0.040 * * *$ & $0.040 * * *$ & $0.039 * * *$ \\
\hline & & 11.37 & 11.37 & 11.12 & & 7.4 & 7.51 & 7.08 & & 5.96 & 6.04 & 5.94 \\
\hline \multirow[t]{2}{*}{$\begin{array}{c}\text { Participation } \\
\text { Ratio } \\
\end{array}$} & & & & $0.092 * * *$ & & & & $0.193 * * *$ & & & & $0.051 * * *$ \\
\hline & & & & 11.36 & & & & 10.89 & & & & 5.59 \\
\hline
\end{tabular}




\begin{tabular}{|c|c|c|c|c|c|c|c|c|c|c|c|c|}
\hline _cons & $20.388^{* * *}$ & $25.156^{* * *}$ & $28.127 * * *$ & $22.302 * * *$ & $21.423^{* * *}$ & $28.104 * * *$ & $35.492 * * *$ & $20.758 * * *$ & $11.662 * * *$ & $15.815 * * *$ & $16.095 * * *$ & $13.631 * * *$ \\
\hline & 19.95 & 20.3 & 17.46 & 13.09 & 14.22 & 14.71 & 9.99 & 5.5 & 4.88 & 6.2 & 5.65 & 4.7 \\
\hline R Adj sq. & 0.251 & 0.272 & 0.273 & 0.285 & 0.345 & 0.365 & 0.367 & 0.393 & 0.047 & 0.069 & 0.07 & 0.076 \\
\hline $\mathrm{N}$ & 10906 & 10906 & 10906 & 10906 & 4922 & 4922 & 4922 & 4922 & 5984 & 5984 & 5984 & 5984 \\
\hline
\end{tabular}

The regression also includes oblast dummies, dummies for different types of schools and evening schools. The full table can be found in excel tables which can be made available upon request. *** means significant at the $1 \%$ level, $* *$ at the $5 \%$ level and * at the 10 percent level.T statistics are based on robust standard errors for the OLS specifications.

Table 10b - Bottom Students, Ukrainian

\begin{tabular}{|c|c|c|c|c|c|c|c|c|c|c|c|c|}
\hline & \multicolumn{4}{|c|}{ Total } & \multicolumn{4}{|c|}{ Urban } & \multicolumn{4}{|c|}{ Rural } \\
\hline & (1) & (2) & (3) & (4) & (1) & (2) & (3) & (4) & (1) & (2) & (3) & (4) \\
\hline \multirow[t]{2}{*}{ \# students } & $-0.013 * * *$ & $-0.013 * * *$ & $-0.018 * * *$ & $-0.015^{* * *}$ & $-0.013 * * *$ & $-0.013 * * *$ & $-0.028 * * *$ & $-0.018 * * *$ & 0.003 & 0.003 & -0.014 & -0.013 \\
\hline & -16.1 & -15.49 & -6.83 & -5.84 & -15.31 & -15.69 & -9.56 & -6.24 & 0.8 & 0.96 & -1.45 & -1.36 \\
\hline \multirow[t]{2}{*}{ (\# students) $^{2}$} & & & $0.000 * * *$ & $0.000 *$ & & & $0.000^{* * *}$ & $0.000^{* * *}$ & & & $0.000^{*}$ & $0.000^{*}$ \\
\hline & & & 2.58 & 1.87 & & & 6.02 & 3.5 & & & 1.85 & 1.79 \\
\hline \multirow[t]{2}{*}{ Student/Teacher } & $0.231 * *$ & $0.231^{* * *}$ & 0.323 & 0.382 & 0.022 & 0.088 & -0.203 & -0.074 & 0.001 & -0.001 & 0.427 & 0.454 \\
\hline & 2.48 & 2.58 & 1.33 & 1.57 & 0.19 & 0.81 & -0.62 & -0.24 & 0.01 & -0.01 & 0.85 & 0.9 \\
\hline \multirow[t]{2}{*}{ (Stud./Teacher) $^{2}$} & & & -0.004 & -0.007 & & & 0.014 & 0.008 & & & -0.016 & -0.017 \\
\hline & & & -0.49 & -0.8 & & & 1.31 & 0.77 & & & -0.63 & -0.7 \\
\hline \multirow[t]{2}{*}{ Class Size } & $0.155^{* * *}$ & $0.125 * * *$ & $0.673 * * *$ & $0.678^{* * *}$ & 0.008 & -0.035 & $0.910^{* * *}$ & $0.862 * * *$ & $0.127 * *$ & $0.130 * *$ & 0.267 & 0.282 \\
\hline & 4.43 & 3.62 & 4.55 & 4.61 & 0.17 & -0.75 & 3.25 & 3.2 & 2.36 & 2.5 & 1.22 & 1.29 \\
\hline \multirow[t]{2}{*}{$(\text { Class Size })^{2}$} & & & $-0.015 * * *$ & $-0.015 * * *$ & & & $-0.021 * * *$ & $-0.020 * * *$ & & & -0.004 & -0.004 \\
\hline & & & -4.19 & -4.31 & & & -3.5 & -3.37 & & & -0.61 & -0.7 \\
\hline \multirow[t]{2}{*}{ Urban } & $-1.132 * *$ & $-1.933 * * *$ & $-1.845^{* * *}$ & $-1.166^{* *}$ & & & & & & & & \\
\hline & -2.27 & -3.93 & -3.48 & -2.18 & & & & & & & & \\
\hline \multirow[t]{2}{*}{ Gender Comp. } & & $0.190^{* * *}$ & $0.190^{* * *}$ & $0.199 * * *$ & & $0.178^{* * *}$ & $0.177 * * *$ & $0.189 * * *$ & & $0.197 * * *$ & $0.197 * * *$ & $0.199 * * *$ \\
\hline & & 14.56 & 14.6 & 15.17 & & 7.42 & 7.49 & 8.37 & & 12.71 & 12.71 & 12.68 \\
\hline \multirow[t]{2}{*}{ Unemployment rate 2009} & & 0.005 & 0.013 & 0.065 & & -0.095 & -0.062 & 0.019 & & 0.134 & 0.122 & 0.135 \\
\hline & & 0.04 & 0.1 & 0.5 & & -0.51 & -0.33 & 0.1 & & 0.78 & 0.71 & 0.78 \\
\hline \multirow[t]{2}{*}{ Average Wage 2009} & & $0.001 *$ & $0.001 *$ & $0.001 * *$ & & $0.002 * * *$ & $0.002 * * *$ & $0.002 * * *$ & & -0.001 & -0.001 & -0.001 \\
\hline & & 1.74 & 1.96 & 2.28 & & 3 & 3 & 3.19 & & -0.73 & -0.67 & -0.6 \\
\hline
\end{tabular}




\begin{tabular}{|c|c|c|c|c|c|c|c|c|c|c|c|c|}
\hline Population & & $-0.010 * * *$ & $-0.008 * * *$ & $-0.008 * *$ & & $-0.006^{*}$ & $-0.007 * *$ & $-0.006^{*}$ & & $-0.146 * * *$ & $-0.138 * * *$ & $-0.131 * * *$ \\
\hline & & -3.3 & -2.69 & -2.52 & & -1.94 & -2.02 & -1.81 & & -4.15 & -3.8 & -3.65 \\
\hline \multirow[t]{2}{*}{ Share Ukrainian } & & $-0.138 * * *$ & $-0.138 * * *$ & $-0.137 * * *$ & & $-0.113 * * *$ & $-0.113 * * *$ & $-0.109 * * *$ & & $-0.151 * * *$ & $-0.151 * * *$ & $-0.151 * * *$ \\
\hline & & -14.6 & -14.62 & -14.66 & & -9.34 & -9.38 & -9.38 & & -9.93 & -9.97 & -9.98 \\
\hline \multirow[t]{2}{*}{ Participation Ratio } & & & & $-0.093 * * *$ & & & & $-0.283 * * *$ & & & & -0.02 \\
\hline & & & & -6.98 & & & & -11.7 & & & & -1.24 \\
\hline \multirow[t]{2}{*}{ _cons } & $19.660 * * *$ & $13.176^{* * *}$ & $9.094 * * *$ & $14.973 * * *$ & $22.591 * * *$ & $14.405^{* * *}$ & $9.827 * * *$ & $31.458 * * *$ & $24.955^{* * *}$ & $18.951 * * *$ & $18.027^{* * *}$ & $18.971 * * *$ \\
\hline & 16.05 & 8.4 & 4.56 & 6.58 & 12.64 & 6.16 & 2.77 & 7.42 & 7.38 & 5.37 & 4.49 & 4.58 \\
\hline R Adj sq. & 0.135 & 0.192 & 0.193 & 0.201 & 0.276 & 0.319 & 0.325 & 0.374 & 0.048 & 0.111 & 0.111 & 0.112 \\
\hline $\mathrm{N}$ & 10906 & 10906 & 10906 & 10906 & 4922 & 4922 & 4922 & 4922 & 5984 & 5984 & 5984 & 5984 \\
\hline
\end{tabular}

The regression also includes oblast dummies, dummies for different types of schools and evening schools. The full table can be found in excel tables which can be made available upon request. *** means significant at the $1 \%$ level, ** at the $5 \%$ level and * at the 10 percent level.T statistics are based on robust standard errors for the OLS specifications. 


\section{d. How good are annual data for measuring educational performance?}

So far we have been using the data from the 2010 EIT. We also have data for the 2008 and 2009 EIT. Given that we have 3 years of data for both inputs and outputs one could argue we can use panel data techniques to estimate the determinants of educational performance in Ukraine. However, yearly test score data can be quite crude measures of educational performance. To illustrate this, we follow Kane and Staiger (2002) who suggest several ways to check to what extent test scores can be used as school level indicators of performance.

First, one can check to what extent scores are correlated over time - that is, to what extent do schools that score well in one year also score well in subsequent years. The idea behind this measure is that one reasonably can expect school quality to be, to a large extent, stable over time. If our school performance measure varies a lot from one year to another year, with changes in one year reverting the next year, our school performance measure is likely to be a noisy indicator of the underlying real school quality. We use the Ukrainian exam as this exam is compulsory for everybody who is interested in further studies, and we use the mean score by school as score indicator.

Figure 2: Correlation in Test Scores

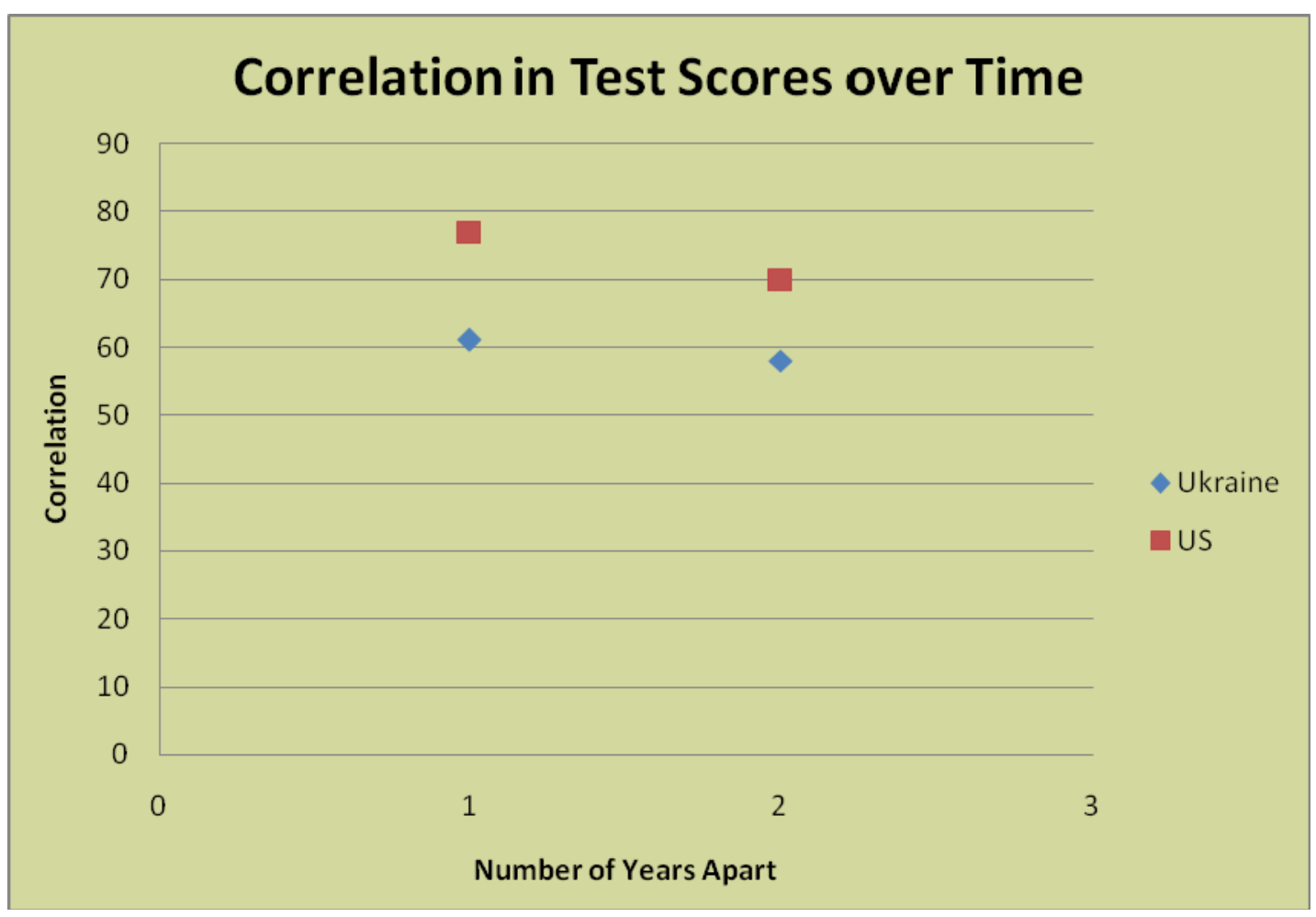


As can be seen from the above figure, the correlation between scores in 2 subsequent years is substantial and positive (about 0.61 in Ukraine) and this correlation decreases over time. Note that the correlation in the US (where fourth grade math scores are used) is substantially higher, but also decreases over time. One explanation for this difference is that secondary schools in the US are substantially bigger - if we restrict the sample to the schools that have more than the median of graduates taking the Ukrainian test, we get correlations close to 0.8 .

Next, one can look to what extent changes in scores are correlated. In case changes are purely random, one would expect increases in one year to be followed by decreases in the next year and the correlation would be -0.5 . Kaine and Staiger (2002) find a correlation of -0.37 for the US data. In our sample of Ukrainian schools, we find -0.465 . This suggests that $93 \%(0.465 / 0.5)$ of the changes from one year to another are transitory rather than permanent ${ }^{30}$. The latter implies that by averaging out yearly variations and taking averages over longer periods one will get closer to the stable underlying school quality variable.

We come to the same conclusion if we use as a performance indicator the percentage of students scoring 150 or above (reflecting to what extent a school's students score (approximately) above the national average, correlations of $0.5,0.46$ and -0.454), the percentage of students scoring below 135.5 (roughly the bottom 20 percent of students, correlations of $0.41,0.37$ and -0.469 ) or the percentage of students scoring above 173 (roughly the top 10\% students, correlations of $0.548,0.513$ and $\left.-0.485^{31}\right)$.

The discussion above argues against using panel data techniques: panel estimation techniques focus on the variation over time while the variation in educational quality over time is expected to be small relative to the variation across schools. In addition, given that changes in inputs over time are also relatively small (compared to the cross-sectional variation and compared to the kind of policy changes we are analyzing here) the effect of errors in variables is likely to be substantial in a panel data set-up.

\footnotetext{
${ }^{30}$ A similar sized correlation is obtained when restricting the sample to the bigger schools (above median number of students taking the Ukrainian test)

${ }^{31}$ It is impossible to aggregate the categories in such a way that the top and the bottom group would be approximately of equal size.
} 
We therefore run regressions using weighted averages of the mean score over the three EITs, 2008-2009-2010, using the students participating in each year as weights. We use these weights both for the dependent and the explanatory variables ${ }^{32}$.

\section{e. $\quad$ Using Weighted Averages over 3 Years}

Table $11 \mathrm{a}$ and $11 \mathrm{~b}$ present the regression results for the participation ratio and the mean Ukrainian score.

Given that we take out part of the random variation by taking weighted averages, it comes to no surprise that the explanatory power of our regressions increases, adding roughly 10 percentage points to the adjusted $\mathrm{R}^{2}$.

In general, the results are similar to what we found above when just using 2010 data, albeit that the sizes of the class and school size effects are slightly smaller.

\footnotetext{
${ }^{32}$ An implicit assumption here is that the production functions are stable over time- this is likely to be a harmless assumption, even though there were slight changes in the organizational procedure of the tests ( f.e. some very specific groups of students were not required to participate) from year to year.
} 
Table 11a - Ukrainian Language, Participation Ratio

\begin{tabular}{|c|c|c|c|c|c|c|c|c|c|c|c|c|}
\hline & \multicolumn{4}{|c|}{ Total } & \multicolumn{4}{|c|}{ Urban } & \multicolumn{4}{|c|}{ Rural } \\
\hline & (1) & (2) & (3) & (1) & (2) & (3) & (1) & (2) & (3) & (1) & (2) & (3) \\
\hline \multirow[t]{2}{*}{ \# students } & $0.011 * * *$ & $0.011 * * *$ & $0.022 * * *$ & $0.022 * * *$ & $0.011 * * *$ & $0.011 * * *$ & $0.028 * * *$ & $0.028 * * *$ & $0.008^{* *}$ & 0 & $0.028 * * *$ & $0.028 * * *$ \\
\hline & 14.94 & 14.76 & 9.51 & 8.74 & 13.48 & 13.39 & 10.59 & 11.88 & 2.49 & -0.13 & 2.74 & 3.48 \\
\hline \multirow[t]{2}{*}{$(\# \text { students })^{2}$} & & & $-0.000 * * *$ & $-0.000 * * *$ & & & $-0.000 * * *$ & $-0.000 * * *$ & & & $-0.000 * *$ & $-0.000 * * *$ \\
\hline & & & -5.92 & -4.67 & & & -8.04 & -7.96 & & & -2.52 & -3.5 \\
\hline \multirow[t]{2}{*}{ Student/Teacher } & -0.047 & 0.017 & $0.552^{* *}$ & $0.577 * * *$ & -0.004 & 0.004 & 0.336 & 0.35 & 0.217 & 0.262 & $1.789 * *$ & $1.826^{* * *}$ \\
\hline & -0.52 & 0.18 & 2.32 & 2.78 & -0.04 & 0.04 & 1.08 & 1.48 & 1.17 & 1.44 & 2.14 & 3.76 \\
\hline \multirow[t]{2}{*}{ (Stud./Teacher) $^{2}$} & & & $-0.029 * * *$ & $-0.030 * * *$ & & & $-0.017 *$ & $-0.017 * *$ & & & $-0.112 * *$ & $-0.113 * * *$ \\
\hline & & & -2.85 & -3.51 & & & -1.68 & -2.03 & & & -2.21 & -4.32 \\
\hline \multirow[t]{2}{*}{ Class Size } & $-0.113^{* * *}$ & $-0.111 * * *$ & $-0.548 * * *$ & $-0.619 * * *$ & $0.108 * *$ & $0.123 * * *$ & $-0.874 * * *$ & $-1.018^{* * *}$ & $-0.181 * * *$ & $-0.199 * * *$ & 0.148 & 0.091 \\
\hline & -3.16 & -3.04 & -3.45 & -4.29 & 2.45 & 2.59 & -2.9 & -4.07 & -3.12 & -3.48 & 0.56 & 0.39 \\
\hline \multirow[t]{2}{*}{$(\text { Class Size })^{2}$} & & & $0.010 * *$ & $0.012 * * *$ & & & $0.022 * * *$ & $0.025 * * *$ & & & $-0.014 *$ & $-0.013^{*}$ \\
\hline & & & 2.48 & 3.02 & & & 3.24 & 4.3 & & & -1.83 & -1.89 \\
\hline \multirow[t]{2}{*}{ urban $==1$} & $7.657 * * *$ & $7.480 * * *$ & $6.874 * * *$ & $6.993 * * *$ & & & & & & & & \\
\hline & 18.36 & 18.23 & 15.66 & 16.69 & & & & & & & & \\
\hline \multirow[t]{2}{*}{ Gender Comp. } & & $0.208^{* * *}$ & $0.209^{* * *}$ & $0.209^{* * *}$ & & $0.053^{*}$ & $0.054 *$ & $0.050^{* *}$ & & $0.258^{* * *}$ & $0.260^{* * *}$ & $0.262 * * *$ \\
\hline & & 12.79 & 12.89 & 15.59 & & 1.85 & 1.92 & 2.53 & & 13.04 & 13.33 & 14.83 \\
\hline \multirow[t]{2}{*}{ Unemployment rate 2009} & & 0.124 & $0.146^{*}$ & $0.152 *$ & & 0.198 & 0.18 & 0.203 & & 0.111 & 0.145 & 0.147 \\
\hline & & 1.48 & 1.73 & 1.89 & & 1.53 & 1.4 & 1.62 & & 1.06 & 1.39 & 1.41 \\
\hline \multirow[t]{2}{*}{ Average Wage 2009} & & 0.001 & 0.001 & 0.001 & & 0 & 0 & 0 & & $0.001 *$ & $0.002^{* *}$ & 0.001 \\
\hline & & 1.51 & 1.41 & 1.27 & & -0.08 & -0.15 & -0.14 & & 1.8 & 1.97 & 1.63 \\
\hline \multirow[t]{2}{*}{ Population } & & 0 & 0 & 0.001 & & 0 & 0.001 & 0.001 & & $1.181 * * *$ & $1.126^{* * *}$ & $1.141 * * *$ \\
\hline & & -0.08 & 0.37 & 0.37 & & 0.3 & 0.6 & 0.72 & & 4.25 & 4.13 & 5.76 \\
\hline \multirow[t]{2}{*}{ Share Ukrainian } & & $0.019^{* * *}$ & $0.019 * * *$ & $0.019 * * *$ & & $0.016^{* *}$ & $0.016^{* *}$ & $0.017^{* *}$ & & $0.021 *$ & $0.022^{* *}$ & $0.022 * *$ \\
\hline & & 2.94 & 2.94 & 3.27 & & 2.01 & 2.08 & 2.54 & & 1.89 & 2.02 & 2.28 \\
\hline \multirow[t]{2}{*}{ _cons } & $85.403 * * *$ & $74.391 * * *$ & $74.494 * * *$ & $75.616^{* * *}$ & $87.765 * * *$ & $84.430^{* * *}$ & $89.448^{* * *}$ & $91.395^{* * *}$ & $82.578^{* * *}$ & $66.452 * * *$ & $55.629 * * *$ & $56.676^{* * *}$ \\
\hline & 86.91 & 50.41 & 38.29 & 40.65 & 66.83 & 36.88 & 25.6 & 31.27 & 27.98 & 20.16 & 12.83 & 13.54 \\
\hline
\end{tabular}




\begin{tabular}{|c|c|c|c|c|c|c|c|c|c|c|c|c|}
\hline sigma & & & & & & & & & & & & \\
\hline & & & & $11.718 * * *$ & & & & $9.146 * * *$ & & & & $12.966^{* * *}$ \\
\hline R Adj sq. & & & & 129.76 & & & & 84.7 & & & & 98.3 \\
\hline $\mathrm{N}$ & 0.408 & 0.425 & 0.428 & & 0.568 & 0.57 & 0.578 & & 0.164 & 0.206 & 0.216 & \\
\hline & 8663 & 8661 & 8661 & 8661 & 3695 & 3695 & 3695 & 3695 & 4968 & 4966 & 4966 & 4966 \\
\hline
\end{tabular}

The regression also includes oblast dummies, dummies for different types of schools and evening schools. The full table can be found in excel tables which can be made available upon request. *** means significant at the $1 \%$ level, $* *$ at the $5 \%$ level and $*$ at the 10 percent level.T statistics are based on robust standard errors for the OLS specifications.

Table 11 - Ukrainian Language, Mean Score

\begin{tabular}{|c|c|c|c|c|c|c|c|c|c|c|c|c|}
\hline & \multicolumn{4}{|c|}{ Total } & \multicolumn{4}{|c|}{ Urban } & \multicolumn{4}{|c|}{ Rural } \\
\hline & (1) & (2) & (3) & (4) & (1) & (2) & (3) & (4) & (1) & (2) & (3) & (4) \\
\hline \multirow[t]{2}{*}{ \# students } & $0.009 * * *$ & $0.009^{* * *}$ & $0.009 * * *$ & $0.007 * * *$ & $0.008 * * *$ & $0.008 * * *$ & $0.016^{* * *}$ & $0.008^{* * *}$ & 0 & -0.002 & $0.010 * * *$ & $0.009 * * *$ \\
\hline & 18.93 & 19.08 & 7.05 & 5.41 & 15.76 & 16.08 & 9.49 & 4.94 & -0.11 & -1.32 & 2.81 & 2.61 \\
\hline \multirow[t]{2}{*}{ (\# students) $^{2}$} & & & 0 & 0 & & & $-0.000 * * *$ & $-0.000 * *$ & & & $-0.000 * * *$ & $-0.000 * * *$ \\
\hline & & & -1.36 & -0.3 & & & -5.28 & -1.98 & & & -3.5 & -3.38 \\
\hline \multirow[t]{2}{*}{ Student/Teacher } & $-0.169 * * *$ & $-0.198 * * *$ & -0.052 & -0.114 & -0.095 & $-0.154 * *$ & -0.09 & -0.186 & 0.097 & 0.057 & 0.175 & 0.112 \\
\hline & -3.77 & -4.57 & -0.42 & -0.96 & -1.49 & -2.5 & -0.46 & -1.02 & 1.37 & 0.84 & 0.87 & 0.54 \\
\hline \multirow[t]{2}{*}{ (Stud./Teacher) $^{2}$} & & & -0.005 & -0.002 & & & -0.002 & 0.003 & & & -0.015 & -0.011 \\
\hline & & & -1.03 & -0.37 & & & -0.36 & 0.43 & & & -1.48 & -1.04 \\
\hline \multirow[t]{2}{*}{ Class Size } & $-0.102 * * *$ & $-0.083 * * *$ & $-0.556 * * *$ & $-0.495 * * *$ & 0.027 & $0.068^{*}$ & $-1.062 * * *$ & $-0.811 * * *$ & $-0.083 * * *$ & $-0.089 * * *$ & -0.087 & -0.092 \\
\hline & -5.04 & -4.15 & -6.29 & -5.72 & 0.77 & 1.85 & -4.44 & -3.79 & -3.18 & -3.58 & -0.72 & -0.77 \\
\hline \multirow[t]{2}{*}{$(\text { Class Size })^{2}$} & & & $0.013 * * *$ & $0.012 * * *$ & & & $0.026^{* * *}$ & $0.020 * * *$ & & & -0.001 & -0.001 \\
\hline & & & 5.57 & 5.23 & & & 4.89 & 4.15 & & & -0.32 & -0.18 \\
\hline \multirow[t]{2}{*}{ Urban } & $1.670 * * *$ & $2.099 * * *$ & $2.061 * * *$ & $1.296^{* * *}$ & & & & & & & & \\
\hline & 7.08 & 9.04 & 8.4 & 5.54 & & & & & & & & \\
\hline \multirow[t]{2}{*}{ Gender Comp. } & & $-0.120 * * *$ & $-0.121 * * *$ & $-0.144 * * *$ & & $-0.136^{* * *}$ & $-0.135^{* * *}$ & $-0.151 * * *$ & & $-0.122 * * *$ & $-0.122 * * *$ & $-0.131 * * *$ \\
\hline & & -15.46 & -15.53 & -18.53 & & -8.31 & -8.27 & -10.44 & & -14.12 & -14.09 & -14.88 \\
\hline \multirow[t]{2}{*}{$\begin{array}{l}\text { Unemployment } \\
\text { rate } 2009\end{array}$} & & 0.029 & 0.036 & 0.02 & & 0.003 & 0.02 & -0.032 & & 0.004 & 0.016 & 0.011 \\
\hline & & 0.67 & 0.84 & 0.47 & & 0.03 & 0.24 & -0.39 & & 0.09 & 0.32 & 0.22 \\
\hline Average Wage & & 0 & 0 & 0 & & -0.001 & -0.001 & -0.001 & & 0 & 0 & 0 \\
\hline
\end{tabular}




\begin{tabular}{|c|c|c|c|c|c|c|c|c|c|c|c|c|}
\hline 2009 & & & & & & & & & & & & \\
\hline & & -0.95 & -1.19 & -1.53 & & -1.27 & -1.35 & -1.41 & & 0.6 & 0.61 & 0.47 \\
\hline \multirow[t]{2}{*}{ Population } & & $0.002 * * *$ & $0.001 *$ & $0.001 *$ & & 0.001 & 0.001 & 0 & & $0.328 * * *$ & $0.303 * * *$ & $0.264 * * *$ \\
\hline & & 2.64 & 1.65 & 1.67 & & 1.05 & 0.76 & 0.55 & & 3.66 & 3.43 & 3.14 \\
\hline \multirow[t]{2}{*}{ Share Ukrainian } & & $0.060 * * *$ & $0.060 * * *$ & $0.058 * * *$ & & $0.046 * * *$ & $0.046 * * *$ & $0.042 * * *$ & & $0.064 * * *$ & $0.065 * * *$ & $0.064 * * *$ \\
\hline & & 16.17 & 16.2 & 16.55 & & 8.64 & 8.87 & 9.34 & & 11.86 & 11.96 & 12.05 \\
\hline \multirow[t]{2}{*}{$\begin{array}{c}\text { Participation } \\
\text { Ratio } \\
\end{array}$} & & & & $0.111 * * *$ & & & & $0.287 * * *$ & & & & $0.035^{* * *}$ \\
\hline & & & & 16.81 & & & & 20.44 & & & & 4.89 \\
\hline \multirow[t]{2}{*}{ _cons } & $155.632 * * *$ & $159.839 * * *$ & $162.916^{* * *}$ & $154.634 * * *$ & $155.255 * * *$ & $160.703^{* * *}$ & $170.099 * * *$ & $144.392 * * *$ & $146.993 * * *$ & $151.392 * * *$ & $149.832 * * *$ & $147.877 * * *$ \\
\hline & 225.59 & 187.01 & 146.63 & 126.33 & 143.91 & 108.96 & 63.07 & 52.27 & 83.11 & 82.73 & 72.38 & 70.85 \\
\hline R Adj sq. & 0.361 & 0.404 & 0.407 & 0.432 & 0.476 & 0.503 & 0.511 & 0.593 & 0.156 & 0.221 & 0.224 & 0.228 \\
\hline $\mathrm{N}$ & 8663 & 8661 & 8661 & 8661 & 3695 & 3695 & 3695 & 3695 & 4968 & 4966 & 4966 & 4966 \\
\hline
\end{tabular}

The regression also includes oblast dummies, dummies for different types of schools and evening schools. The full table can be found in excel tables which can be made available upon request. $* * *$ means significant at the $1 \%$ level, ** at the $5 \%$ level and * at the 10 percent level.T statistics are based on robust standard errors for the OLS specifications. 


\section{Conclusions}

The empirical analysis undertaken in this study points to the fact that the size of schools and classes does not appear to be very important for the educational quality of secondary schools in Ukraine, a finding that is broadly in line with what has been found for other countries and hence there is little evidence for a trade-off between efficiency and quality. In the case of Ukraine, if anything, our findings are suggestive that school size has a small positive effect and that class size has no significant effect on school performance.

Table 12a and 12b summarize the effects of class size and school size across specifications. Our results show that bigger schools tend to have higher participation ratios and tend to have higher mean test scores, more students among the top students and less students among the bottom students. This is especially true for urban schools, where the difference between the $25^{\text {th }}$ percentile (about 300 students) and the $75^{\text {th }}$ percentile (over 600 students) of the school size distribution is about 4 test score points and about 7 percentage points in terms of participation ratio. For the rural schools, the effect of moving from the $25^{\text {th }}$ percentile (about 100 students) and the $75^{\text {th }}$ percentile (over 200 students) of the school size distribution is substantially smaller, at roughly half the values found for urban schools. At the same time, the rural area estimates are likely to be less affected by a possible endogeneity bias.

Since increasing the size of schools, on average, will result in an increase in the size of classes, we could wonder what would happen with performance. Indeed, not much. Going from the $25^{\text {th }}$ percentile to the $75^{\text {th }}$ percentile of the class size distribution does not affect the performance much, relative to going from the $25^{\text {th }}$ percentile to the $75^{\text {th }}$ percentile of the school size distribution - often the difference is even insignificant and sometimes the difference is even positive.

Our estimates also imply that there seems to be an 'optimal' size, a point after which further increasing school size goes together with lower mean scores. Our estimates of that point (which varies from about 400 for rural schools to over 1000 for urban schools), however, show that few Ukrainian schools already have reached that point. Our estimated optimal point is also substantially higher than 100 students suggesting that the 100 -student cut-off point used by the 
Ukrainian government in the Budget Declaration 2011 for ordering the optimization of complete schools (levels I-III) may be very conservative, especially for urban schools, almost none of which are below this threshold and for which the estimated optimal point is often over 1000. This suggests there is a lot of room for consolidation.

From a policy point of view, our findings suggest that consolidating the network of schools through a downsizing in the number of small schools and a transfer process of students in those schools to neighboringones is unlikely to harm school performance on the EIT. If anything it may even increase educational outcomes. Of course, an important caveat here is that this "no harm conclusion" is only likely to hold if the organization of the transfer and of the commuting to the receiving schools is organized efficiently.

While our results are suggestive, they further need to be interpreted with caution as we have not been able to investigate in detail to what extent our findings reflect causal relationships rather than correlation. Nor can we claim that these empirical findings can be extended to schools other than complete schools (level I-III), since the analysis was undertaken with measures of school performance for $12^{\text {th }}$-graders. Both these areas remain avenues for further research as well as the analysis of the student-level EITdata as opposed to the school-level analysis presented here ${ }^{33}$.

The consolidation of the network of schools in Ukraine is an important area of reform for improving the efficiency of educational spending and for achieving fiscal sustainability of the sector. If managed well, a sound optimization strategy can bring tangible results on the access, equity and quality fronts. But rationalizing the network of schools is usually one of the most difficult education reforms since it usually faces with strong resistance in communities, and among parents and teachers. Therefore, a necessary pre-requisite to embark in such reforms is a strong political will and coordinated efforts of Government agencies and local authorities to materialize. A detailed roadmap with a thorough nationwide analysis and realistic investment plans should be clearly defined. And public campaigns need to be incorporated as an essential

33 In a first attempt, Thoryk (2011) uses 2007 TIMSS data to estimate the effect of school size on school performance in transition countries. Overall his country specific estimates suggest there is little relation between school size and performance. His results for Ukraine suggest an insignificant effect of size on $4^{\text {th }}$ grade science and $8^{\text {th }}$ grade mathematics, an inverted $U$ shape for 4 th year math and a U-shaped relationship for $8^{\text {th }}$ grade science. While the latter two results are significant, the size of the effect is found to be negligible. 
component so as to ensure wide dissemination of the rationale behind it and a clear explanation of how benefits from optimization will outweigh costs for all key stakeholders. 
Table 12a: Effect ofschool size, difference in dependent variable, relative to median school size

\begin{tabular}{|c|c|c|c|c|c|c|}
\hline Dependent Variable & type & First Quartile & Median & Third Quartile & At Max & Max at \\
\hline Participation Ratio (Ukrainian) & urban & -3.8 & 0 & 3.5 & 6.3 & 1060 \\
\hline Participation Ratio (Ukrainian) & rural & -1.5 & 0 & 2 & 5.6 & 470 \\
\hline Average Ukrainian Score & urban & -2 & 0 & 2 & 6.4 & 1600 \\
\hline Average Ukrainian Score & rural & -0.4 & 0 & 0.5 & 1.3 & 427 \\
\hline Average Mathematics Score & urban & -2 & 0 & 2.1 & 6.8 & 1641 \\
\hline Average Mathematics Score & rural & -0.4 & 0 & 1.3 & 3.1 & 443 \\
\hline Average Ukrainian History Score & urban & -1 & 0 & 1.2 & 8.5 & 2159 \\
\hline Average Ukrainian History Score & rural & -0.3 & 0 & 0.5 & 1.1 & 422 \\
\hline Average Ukrainian Score - Female Students & urban & -1.8 & 0 & 1.9 & 5.9 & 1584 \\
\hline Average Ukrainian Score - Female Students & rural & -0.6 & 0 & 0.8 & 2 & 446 \\
\hline Average Ukrainian Score - Male Students & urban & -2 & 0 & 2.1 & 7.5 & 1762 \\
\hline Average Ukrainian Score - Male Students & rural & -0.6 & 0 & 0.8 & 2 & 446 \\
\hline$\%$ students having $>173$ on the Ukrainian Exam & urban & -2 & 0 & 2.3 & 15.6 & 3065 \\
\hline$\%$ students having $>173$ on the Ukrainian Exam & rural & -0.7 & 0 & 1 & 3.1 & 538 \\
\hline$\%$ students having $<135.5$ on the Ukrainian Exam & urban & 3.2 & 0 & -3.2 & -7.5 & 1291 \\
\hline$\%$ students having $<135.5$ on the Ukrainian Exam & rural & 0.36 & 0 & -0.4 & -0.7 & 316 \\
\hline Participation Ratio - weighted average variables & urban & -2.9 & 0 & 2.7 & 4.9 & 1105 \\
\hline Participation Ratio - weighted average variables & rural & -0.9 & 0 & 1.1 & 2.5 & 430 \\
\hline Average Ukrainian Score- weighted average variables & urban & -1.8 & 0 & 1.8 & 4.8 & 1408 \\
\hline Average Ukrainian Score- weighted average variables & rural & -0.3 & 0 & 0.3 & 0.5 & 344 \\
\hline
\end{tabular}

Differences are percentage points for the participation ratios and points for the test scores

For the 2010 regressions, school quartiles are at about 100, 140 and 210 for rural areas and 305,465 and 666 for urban areas. For the weighted average regressions, quartiles are at 110,154 and 225 for rural areas and 322, 484 and 685 for urban areas 
Table 12b: Effect of class size, difference in dependent variable, relative to median class size

\begin{tabular}{|c|c|c|c|c|c|c|c|}
\hline Dependent Variable & Type & First & Media & Third & at & Max/Min & Signif. \\
\hline Participation Ratio (Ukrainian) & urban & -0.2 & 0 & 0.4 & -0.3 & 14.9 & NS \\
\hline Participation Ratio (Ukrainian) & rural & -0.5 & 0 & -0.4 & 0 & 13.1 & $\mathrm{~S}$ \\
\hline Average Ukrainian Score & urban & 0.1 & 0 & 0.2 & 0 & 20.8 & $\mathrm{~S}$ \\
\hline Average Ukrainian Score & rural & 0.4 & 0 & -0.3 & -0.6 & 28 & Almost \\
\hline Average Mathematics Score & urban & -0.1 & 0 & 0.2 & -0.1 & 17.9 & Almost \\
\hline Average Mathematics Score & rural & 0.3 & 0 & -0.3 & -1.3 & 55.2 & NS \\
\hline Average Ukrainian History Score & urban & 0.1 & 0 & 0.2 & 0 & 21.5 & $\mathrm{~S}$ \\
\hline Average Ukrainian History Score & rural & 0.7 & 0 & -0.5 & -0.7 & 22.4 & $\mathrm{~S}$ \\
\hline Average Ukrainian Score - Female Students & urban & 0 & 0 & 0.22 & 0 & 20.1 & $\mathrm{~S}$ \\
\hline Average Ukrainian Score - Female Students & rural & 0.4 & 0 & -0.3 & -0.6 & 25.6 & Almost \\
\hline Average Ukrainian Score - Male Students & urban & 0.1 & 0 & 0.3 & 0 & 21 & $\mathrm{~S}$ \\
\hline Average Ukrainian Score - Male Students & rural & 0.6 & 0 & -0.6 & -1 & 28.4 & Almost \\
\hline \% students having $>$ 173 on the Ukrainian Exam & urban & -0.1 & 0 & 0.6 & -0.1 & 19.1 & $\mathrm{~S}$ \\
\hline \% students having $>$ 173 on the Ukrainian Exam & rural & 0.4 & 0 & -0.3 & -0.5 & 23.8 & NS \\
\hline \% students having < 135.5 on the Ukrainian & urban & -0.2 & 0 & -0.4 & 0 & 21.2 & $\mathrm{~S}$ \\
\hline \% students having < 135.5 on the Ukrainian & rural & -0.7 & 0 & 0.6 & 1.9 & 35.3 & $\mathrm{NS}$ \\
\hline Participation Ratio - weighted average variables & urban & -0.2 & 0 & 0.5 & -0.2 & 20.3 & $\mathrm{~S}$ \\
\hline Participation Ratio - weighted average variables & rural & 0.9 & 0 & -1.4 & 1.4 & 5.2 & Almost \\
\hline Average Ukrainian Score- weighted average & urban & -0.2 & 0 & 0.6 & -0.2 & 20.3 & S \\
\hline Average Ukrainian Score- weighted average & rural & 0.4 & 0 & -0.5 & 3.2 & -38 & NS \\
\hline
\end{tabular}

Differences are percentage points for the participation ratios and points for the test scores

For the 2010 regressions, school quartiles are at about 100, 140 and 210 for rural areas and 305,465 and 666 for urban areas. For the weighted average regressions, quartiles are at 110,154 and 225 for rural areas and 322, 484 and 685 for urban areas 


\section{References}

Ahn, J., \& Brewer, D. J. (2009). What do we know about reducing class and school size? In G. Sykes, B. Schneider \& D. N. Plank (Eds.), AERA Handbook of Education Policy Research (pp. 426-437). New York: Routledge.

Ammermüller, Andreas, Heijke, Hans and LudgerWößmann (2003). Schooling Quality in Eastern Europe: Educational Production During Transition Research. Centre for Education and the Labour Market, ROA-RM-2003/2E, Maastricht, March 2003.

Andrews, Matthew, Duncombe, William and John Yinger (2002). Revisiting economies of size in American education: are we any closer to a consensus? Economics of Education Review 21 (2002), p. 245-262.

Babcock, Philip and Julian R. Betts (2009). Reduced-Class Distinctions: Effort, Ability, And The Education Production Function. NBER Working Paper 14777, March 2009

Barro, Robert J. and Jong-Wha Lee (2010). A New Data Set Of Educational Attainment In The World, 1950-2010, NBER Working Paper 15902, April 2010.

Berdashkevich, A. and V. Vlasov (2010).Prospects of the Development of the Rural Schools. Russian Education and Society, vol. 52, no. 11, November 2010, pp. 59-71.

Berry, Christopher and Martin West (2005). Growing Pains: The School Consolidation Movement and Student Outcomes, Harris School of Public Policy Studies, University of Chicago, Working paper 0703.

Berryman, S.E. 2000 Hidden Challenges to Education Systems in Transtion Countries. Washington D.C.: The World Bank.

Bukowska, Grazyna and Joanna Siwinska-Gorzelak (2010). School competition and the quality of education: introducing market incentives into public services. The case of Poland.Economics of Transition. Volume 19(1) 2011, 151-177 
Coupé, Tom, Anna Olefir and Juan Diego Alonso (2010), Are Location and School Size Important for Educational Achievement? - An Investigation of the Determinants of the Performance of Secondary Schools in Ukraine, mimeo

Duflo, Esther, Dupas, Pascaline and Michael Kremer (2009). Additional Resources versus Organizational Changes in Education: Experimental Evidence from Kenya, 9 May 2009.

Filer, Randall K. and Daniel Münich (2002). Responses Of Private And Public Schools To Voucher Funding. Center for Economic Research and Graduate Education - Economic Institute, Prague, WP 160, June 2002.

Freeman, Richard B., Machin, Stephen and Martina Viarengo (2010). Variation In Educational Outcomes And Policies Across Countries And Of Schools Within Countries. NBER Working Paper 16293, August 2010.

Garrett, Zoe, Newman, Mark, Elbourne, Diana, Bradley, Steve, Taylor, Jim, West, Anne, Noden, Philip, Sinclair, Jennifer, Fincham, Lorraine, Meetoo, Veena and Tom Korolewicz (2004). Secondary school size: a systematic review. The EPPI-Centre, Social Science Research Unit, Institute of Education, University of London.

Glewwe, Paul (2002). Schools and Skills in Developing Countries: Education Policies and Socioeconomic Outcomes. Journal of Economic Literature, Vol. 40, No. 2 (Jun., 2002), pp. 436482

Glewwe, Paul and Michael Kremer (2005).Schools, Teachers, and Education Outcomes in Developing Countries. CID Working Paper No. 122, September 2005

Hanushek, Eric A. and Javier A. Luque (2002) Efficiency and Equity In Schools Around The World. NBER Working Paper 8949, May 2002

Hanushek, Eric A. (2003). The Failure of Input-Based Schooling Policies. The Economic Journal, Vol. 113, No. 485, Features (Feb., 2003), pp. F64-F98

Hanushek, Eric A.(1995), Interpreting Recent Research on Schooling in Developing Countries, World Bank Research Observer 10(2), p227-46 
Hanushek, Eric and LudgerWoessmann (2007), The Role Of School Improvement In Economic Development, NBER Working Paper 12832

Hanushek, Eric A. and LudgerWoessmann (2010), The Economics Of International Differences In Educational Achievement, NBER Working Paper 15949

Hazans, Mihails (2010). Teacher Pay, Class Size and Local Governments: Evidence from the Latvian Reform. IZA Discussion Paper No. 5291, October 2010

Herbst, Mikolaj (2004). Human Capital Formation In Poland. Where Does Educational Quality Come From? MPRA Paper No. 6001, April 2004

Herczynski, Jan and MikołajHerbst (2005).School Choice and Student Achievement.Evidence from Poland. MPRA Paper No. 6138, 2005

Hermann, Zoltan (2005). Small village-schools and efficiency loss due to diseconomies of scale.In Hermann Z. ed. Efficiency problems in the public education. Budapest: National Institute for Public Education, 2005, 73-87.

Hermann, Zoltan (2004a), Estimating primary school effectiveness from secondary schooling data: the case of Hungary, working paper

Hermann, Zoltan (2004b), Demographic change and the efficiency of primary schools in Hungary, working paper.

Heyneman, Stephen P. and William A. Loxley (1983). The Effect of Primary-School Quality on Academic Achievement Across Twenty-nine High and Low-Income Countries. The American Journal of Sociology, Vol. 88, No. 6 (May, 1983), pp. 1162-1194

Horn, Daniel (2006). Do Small Settlement Schools Provide Education of Inferior Quality? The Case of Hungary. CEU Political Science Journal (CEU Political Science Journal), issue: 01 / 2006, pages: 04-13.

Jakubowski, Maciej and PawelSakowski (2006).Quasi-Experimental Estimates of Class Size Effect in Primary Schools in Poland. MPRA Paper No. 4958, 15 March 2006. 
Kallai, Ella and MirceaManiu (2004). Input Efficiency in Publicly Provided Education: The Case of Romania. Babes-Bolyai University, Cluj-Napoca, Romania.

Kenny, Lawrence W. (1982). Economies of Scale in Schooling. Economics of Education Review, vol. 2, no. 1 (Winter 1982): 1-24.

Kovtunets, Volodymyr, Igor Likarchuk, SergiyRakov,VictorGudzynsky (undated) Quality of Universities Admission Based on External Independent Assessment in Ukraine, working paper

Kuddo, Arvo (2009). Structural Educational Reform: Evidence from a Teacher's Displacement Program in Armenia. World Bank, SP Discussion Paper No. 0902.

Lazear, Edward P. (1999). Educational Production. NBER Working Paper 7349, September 1999

Leithwood, Kenneth and Doris Jantzi (2009). "A Review of Empirical Evidence About School Size Effects: A Policy Perspective". Review of educational research, March 2009 vol. 79 no. 1 $464-490$

Leung, Ambrose and J. Stephen Ferris (2008).School size and youth violence. Journal of Economic Behavior \& Organization, Vol. 65 (2008) 318-333

Liu, Chengfang, Zhang, Linxiu, Luo, Renfu and Scott RozelleThe Effect of Primary School Mergers on Academic Performance of Students in Rural China. Stanford Working paper 205, Sept. 2009

MacDonald, Kevin, Patrinos, Harry and Emilio Porta (2009).Using PISA to Understand the Determinants of Learning.School size and achievement in Serbia.World Bank education working paper, 2009.

McGuinness, Aims, General Rapporteur, Steven Bakker, NeilsHummeluhr, Graham Reid, AnaMaria Sandi, PéterSoltész, Evelyn Viertel, and Ian Whitman (2001). OECD Centre for CoOperation with Non-Members.Reviews of National Policies for Education. Estonia.

Muravyev, Alexander \& Talavera, Oleksandr, 2010. "Can State Language Policies Distort Students' Demand for Higher Education?," IZA Discussion Papers 5411, Institute for the Study of Labor (IZA) 
NiazAsadullah, M. (2005), The effect of class size on student achievement: evidence from Bangladesh," Applied Economics Letters , vol. 12(4), pages 217-221, March

Porta, Emilio (2011). Using PISA to Understand the Determinants of Learning.School size and achievement in Romania.World Bank working paper draft, 2011.

Psacharopoulos, George \& Harry Anthony Patrinos, 2004. "Returns to investment in education: a further update," Education Economics, Taylor and Francis Journals, vol. 12(2), pages 111-134, August

Schady, N., L. Sondergaard, C. Bodewig, T.P. Sohnesen. 2009. "School Closures Impact on Dropout Rates: Main Results and Lessons for the Future.” World Bank and the Task Force on Impact Evaluation

Schütz, G. (2006) 'School Size and Student Achievement in TIMSS 2003'. In Loveless, T. (ed.) Lessons Learned: What International Assessments Tell Us about Mathematics Achievement. Washington, DC: Brookings Institution Press.

Smet, Mike (2001). Determining the optimal size of study fields in Flemish secondary education. Economics of Education Review, 20 (2001) 443-457.

Stiefel, Leanna, Schwartz, Amy Ellen, Iatarola, Patrice and Colin C. Chellman (2009). Mission matters: The cost of small high schools revisited. Economics of Education Review 28 (2009) 585-599

Tkhoryk, Oleg (2011), “ School Size as a Determinant of Educational Performance in Transition Countries”, Kyiv School of Economics, Unpublished Master of ArtsThesis.

Ulubaşoğlu, Mehmet A. and Buly A. Cardak (2006). International Comparisons Of Rural/Urban Educational Attainment: Data And Determinants. Deakin University, School Of Accounting, Economics And Finance, Working Paper SWP 2006/13.

Urquiola, Miguel (2006), Identifying Class Size Effects In Developing Countries: Evidence From Rural Bolivia, The Review Of Economics And Statistics, February 2006, 88(1): 171-177 
Vignoles A., Levacic, R., Walker, J., Machin, S. and Reynolds, D. (2000). The relationship between resource allocation and pupil attainment: a review, DPUQ, Centre for the Economics of Education, LSE (November, 2000).

Walsh, Patrick (2010). Is parental involvement lower at larger schools? Economics of Education Review 29 (2010) 959-970

Wößmann, Ludger (2003). Schooling Resources, Educational Institutions and Student Performance: the International Evidence. Bulletin Of Economics And Statistics, 65, 2 (2003) 0305-9049.

Wößmann, Ludger and Martin R. West (2002). Class-Size Effects in School Systems Around the World: Evidence from Between-Grade Variation in TIMSS. Kiel Working Paper No. 1099, March 2002

World Bank (2010); “A Review of the Bulgaria School Autonomy Reforms”, Report No. 54890BG, Human Development Department, Europe and Central Asia Region, The World Bank. 


\section{Appendix}

\section{Appendix A1 - The Creation of the Database}

The initial database (called EITdatabase henceforth) is based on the public files provided by the Ukrainian Center for Education Quality Monitoring (UCEQMhttp://www.testportal.gov.ua/). This center provides every year the school level results of the central tests (http://www.testportal.gov.ua/index.php/text/vidp/) but does not keep previous year's files available. Moreover, the scores are provided as part of an exe-file which makes large scale analysis very difficult. To make these data more accessible, we created the EITdatabase in Excel format and matched the school level data of the years 2008, 2009 and 2010.

The starting point for our analysis wereUCEQM's exe files for 2008, 2009 and 2010. In these files, each 'rayon' is represented as a sheet with the results for that rayon's schools. These sheets can be extracted as excel files but unfortunately, it is impossible to automatize this process. Hence, all rayon sheets had to be extracted manually. Given there are, for each year, about 750 rayons and about 10 subjects, this meant extracting about 22000 excel sheets one by one ${ }^{34}$. After extracting all sheets we merged all excel sheets into one big excel file per year using Ron De Bruin's Excel RDBMerge Add-In (http://www.rondebruin.nl/merge.htm).

Another disadvantage of the UCEQM exe files is that schools are represented with different names in different years ( for example, Kyiv School Nr 1 could be School Nr 1, Kyiv in another year). While there was a considerable degree of consistency in names between 2009 and 2010, the naming consistency between 2008 and 2009 was limited. To enable comparisons over years, we therefore manually standardized school names and created unique id's for each school - the id starts with the number for the oblast, followed by the number for the rayon, followed by a number for the name of the school and followed by the number for the specialization of the school.

The EIT database further includes information on the number of students taking the test in a given subject and the distribution of scores over 10 categories.

\footnotetext{
${ }^{34}$ We thank EliahSobko and Leonid Dahno for assistance in doing this.
} 
We identify a total of 14043 different schools (see overview 27122010 file), of which 12068 are present in 2010, 12268 in 2009 and 13680 in 2008. That there are more schools in 2008 is because in later years the more professionally oriented schools were no longer included in the EIT database. Most schools, 11523 to be precise or about $82 \%$, were present in each of these three years.

Note that the EIT database also includes information on rayon totals, which explains why there are more than 14043 simplified unique ids.

After matching the EIT data of the different years, we next matched the data of the EIT to a database with information from the Ukrainian Ministry of Education (MoE) the total number of students, the number of teachers and non-teaching staff, and the number of classes and students by grade. Because the school names were not standardized between the EIT database and the MoE, we manually matched the names of the two databases.

We performed several checks and double checks to test the accuracy of our standardization and our matching and to make corrections where necessary. Minor mistakes might remain however (they are hard to avoid and detect when matching names of over 10000 schools).

The MoE database also includes schools that do not offer third cycle classes ( like primary schools) but has only partial coverage of private schools, special schools (like for deaf or blind people), professional schools or evening schools. We were able to match most schools: for 2010 we have 11686 schools in both EIT and MOE (out of 12068 EIT schools), for 200911941 schools out of 12268 and for 2008, 11972 schools out of 13680. We have 11194 schools for which we have information in all years for both the EIT and the MOE database (see overview 27 122010 file).

Finally, we obtained additional data with mean and median scores, gender specific means and median scores, and language and gender composition from the EIT center at the Ministry of Education. Also these data were added to the database. 
Appendix A2The Bias of having test-based composition indicators rather than classbased composition indicators.

Rus $=\#$ Russian speaking students

$\mathrm{Ukr}=\#$ Ukrainian speaking students

$\mathrm{I}=$ participation ratio of Russian speaking students

$\mathrm{I}=$ participation ratio of Ukrainian speaking students

TotalParticipationRatio $=\frac{i * R u s+j * U k r}{R u s+U k r}$

ClassComp $=\frac{U k r U k r+R u s}{}$

RegressionAnalysis: $\frac{i * R u s+j * U k r}{R u s+U k r}=i+(j-i) \frac{U k r}{R u s+U k r}$

Note here that a regression of the total participation ratio on the class composition will give the difference in participation rates of the language groups as coefficient of the class composition variable.

WhatifregressonTestComp $=\frac{j * U k r}{i * R u s+j * U k r}$

$\frac{j * U k r}{i * R u s+j * U k r}=\frac{U k r}{\frac{i}{j} * R u s+U k r}$

So the difference between the Class Composition and the Test Composition will be small if

- The ratio I on $\mathrm{J}$ is close to one - that is, the difference in participation rates of the language groups is small. Under a null hypothesis that the participation ratio of both groups are equal, class composition would equal test composition and hence there would be no bias

- If the number of Russian speakers is small relative to the number of Ukrainian speakers 
In terms of regression coefficient, we should compare

$\frac{\operatorname{cov}\left(\frac{j * U k r}{i * R u s+j * U k r}, \frac{i * R u s+j * U k r}{R u s+U k r}\right)}{\operatorname{var}\left(\frac{j * U k r}{i * R u s+j * U k r}\right)}$

to

$\frac{\operatorname{cov}\left(\frac{U k r}{R u s+U k r}, \frac{i * R u s+j * U k r}{R u s+U k r}\right)}{\operatorname{var}\left(\frac{U k r}{R u s+U k r}\right)}$

It is not straightforward to show the bias here. However, a simulation with a set up similar to ours suggest that it inflates the absolute value of the coefficient 


\begin{tabular}{|c|c|c|c|c|c|c|c|}
\hline Country & Study & Methodology & $\begin{array}{l}\text { Dependent } \\
\text { variable }\end{array}$ & Findings & School size & Class size & $\begin{array}{l}\text { Student- } \\
\text { teacher ratio }\end{array}$ \\
\hline US & $\begin{array}{l}\text { Berry and } \\
\text { West } \\
(2005)\end{array}$ & GLS & $\begin{array}{l}\text { Years of } \\
\text { schooling, } \\
\text { returns to } \\
\text { education } \\
\text { (salary) }\end{array}$ & $\begin{array}{l}\text { Students in smaller } \\
\text { schools get much } \\
\text { higher returns to } \\
\text { education }\end{array}$ & $\begin{array}{l}\text { Negative } \\
\text { significant }\end{array}$ & $\begin{array}{l}\text { Not } \\
\text { considered }\end{array}$ & $\begin{array}{l}\text { Negative } \\
\text { significant }\end{array}$ \\
\hline US & $\begin{array}{l}\text { Leung and } \\
\text { Ferris } \\
(2006)\end{array}$ & Logit & $\begin{array}{l}\text { An } \\
\text { individual } \\
\text { engaged in } \\
\text { violent } \\
\text { behavior } \\
\text { during a } \\
\text { year }\end{array}$ & $\begin{array}{l}\text { Violent behavior rises } \\
\text { with school size (more } \\
\text { than } 2000 \text { students) } \\
\text { and is higher in poor } \\
\text { neighborhoods. It's } \\
\text { also higher for } \\
\text { children which are } \\
\text { members of a gang } \\
\text { and have less than } 2 \\
\text { parents. }\end{array}$ & $\begin{array}{l}\text { Positive } \\
\text { significant }\end{array}$ & $\begin{array}{l}\text { Not } \\
\text { considered }\end{array}$ & $\begin{array}{l}\text { Not } \\
\text { considered }\end{array}$ \\
\hline Belgium & $\begin{array}{l}\text { Smet } \\
(2000)\end{array}$ & $\begin{array}{l}\text { Optimization } \\
\text { (cost-benefit } \\
\text { analysis) }\end{array}$ & $\begin{array}{l}\text { Cost of } \\
\text { getting to } \\
\text { school plus } \\
\text { cost of } \\
\text { studies }\end{array}$ & $\begin{array}{l}\text { An optimal school size } \\
\text { is counted weighting } \\
\text { schooling and } \\
\text { transportation cost. } \\
\text { Actual school size is } \\
\text { less than optimal. }\end{array}$ & $\begin{array}{l}\text { School } \\
\text { increase would } \\
\text { increase } \\
\text { efficiency. }\end{array}$ & $\begin{array}{l}\text { Not } \\
\text { considered }\end{array}$ & $\begin{array}{l}\text { Not } \\
\text { considered }\end{array}$ \\
\hline
\end{tabular}




\begin{tabular}{|c|c|c|c|c|c|c|c|}
\hline NY city & $\begin{array}{l}\text { Stiefel et al } \\
(2009)\end{array}$ & Panel data & $\begin{array}{l}\text { Cost of } \\
\text { schooling }\end{array}$ & $\begin{array}{l}\text { Optimal size for } \\
\text { comprehensive } \\
\text { schools is higher than } \\
\text { for themed schools. } \\
\text { Currently schools are } \\
\text { smaller than optimal. }\end{array}$ & $\begin{array}{l}\text { A U-shape, but } \\
\text { currently } \\
\text { schools are on } \\
\text { a downward } \\
\text { part of the } \\
\text { curve. }\end{array}$ & $\begin{array}{l}\text { Not } \\
\text { considered }\end{array}$ & $\begin{array}{l}\text { Not } \\
\text { considered }\end{array}$ \\
\hline $\begin{array}{l}70 \\
\text { developed } \\
\text { and } \\
\text { developing } \\
\text { countries, } \\
\text { including } 5 \\
\text { transitions } \\
\text { ones }\end{array}$ & $\begin{array}{l}\text { Ulubaşoğlu, } \\
\text { and Cardak } \\
(2006) \text {. }\end{array}$ & GLS & $\begin{array}{l}\text { Ratio of } \\
\text { levels of } \\
\text { urban and } \\
\text { rural } \\
\text { schooling }\end{array}$ & $\begin{array}{l}\text { In poorer, post- } \\
\text { colonial and post-war } \\
\text { countries this } \\
\text { difference is higher. }\end{array}$ & Not considered & $\begin{array}{l}\text { Not } \\
\text { considered }\end{array}$ & $\begin{array}{l}\text { Negative } \\
\text { significant }\end{array}$ \\
\hline US & $\begin{array}{l}\text { Walsh } \\
(2010)\end{array}$ & Ordered logit & $\begin{array}{l}\text { Parental } \\
\text { involvement } \\
\text { into school } \\
\text { matters over } \\
\text { years (start, } \\
\text { no change, } \\
\text { stop) }\end{array}$ & $\begin{array}{l}\text { School size negatively } \\
\text { affects parental } \\
\text { involvement due to } \\
\text { free-riding issues. }\end{array}$ & $\begin{array}{l}\text { Negative } \\
\text { significant }\end{array}$ & $\begin{array}{l}\text { Not } \\
\text { considered }\end{array}$ & $\begin{array}{l}\text { Not } \\
\text { significant }\end{array}$ \\
\hline $\begin{array}{l}\text { Argentina, } \\
\text { Colombia, } \\
\text { Turkey, } \\
\text { Macedonia, } \\
\text { Germany, } \\
\text { Greece, }\end{array}$ & $\begin{array}{l}\text { Wossmann } \\
\text { and Fuchs } \\
(2005)\end{array}$ & GLS & $\begin{array}{l}\text { PIRLS } \\
\text { reading test }\end{array}$ & $\begin{array}{l}\text { Parents' } \\
\text { positive, immigrant } \\
\text { children } \\
\text { disadvantaged, } \\
\text { children from large } \\
\text { cities }\end{array}$ & Not considered & $\begin{array}{l}\text { Not } \\
\text { considered }\end{array}$ & $\begin{array}{l}\text { Not } \\
\text { considered }\end{array}$ \\
\hline
\end{tabular}




\begin{tabular}{|l|l|l|l|l|l|}
\hline Italy, & & & $\begin{array}{l}\text { relatively better in } \\
\text { England }\end{array}$ & $\begin{array}{l}\text { } \\
\text { but woping countries } \\
\text { developed ones. in }\end{array}$ & \\
\hline
\end{tabular}




\begin{tabular}{|c|c|c|c|c|c|c|c|}
\hline Country & Study & Methodology & $\begin{array}{l}\text { Dependent } \\
\text { variable }\end{array}$ & Findings & School size & Class size & $\begin{array}{l}\text { Student- } \\
\text { teacher ratio }\end{array}$ \\
\hline $\begin{array}{l}\text { Czech } \\
\text { Republic, } \\
\text { Slovak } \\
\text { Republic, } \\
\text { Hungary, } \\
\text { Slovenia, } \\
\text { Lithuania, } \\
\text { Latvia, } \\
\text { Romania }\end{array}$ & $\begin{array}{l}\text { Ammermuller } \\
\text { et al (2003) }\end{array}$ & $\begin{array}{l}\text { Clustering- } \\
\text { robust linear } \\
\text { regression } \\
\text { (least squares } \\
\text { and fixed } \\
\text { effects) }\end{array}$ & $\begin{array}{l}\text { TIMSS Math } \\
\text { and Science } \\
\text { test scores }\end{array}$ & $\begin{array}{l}\text { The most significant } \\
\text { is student background, } \\
\text { with family } \\
\text { background next. } \\
\text { School autonomy is } \\
\text { negative but mostly } \\
\text { insignificant. }\end{array}$ & $\begin{array}{l}\text { Not } \\
\text { considered }\end{array}$ & $\begin{array}{l}\text { Significant } \\
\text { but the sign } \\
\text { of effect } \\
\text { differs by } \\
\text { countries }\end{array}$ & $\begin{array}{l}\text { Not } \\
\text { considered }\end{array}$ \\
\hline $\begin{array}{l}37 \\
\text { countries } \\
\text { including } 8 \\
\text { transition } \\
\text { ones }\end{array}$ & $\begin{array}{l}\text { Hanushek and } \\
\text { Luque (2002) }\end{array}$ & $\begin{array}{l}\text { Education } \\
\text { production } \\
\text { function }\end{array}$ & $\begin{array}{l}\text { TIMSS } \\
\text { scores }\end{array}$ & $\begin{array}{l}\text { Family background is } \\
\text { more important than } \\
\text { school characteristics. } \\
\text { Teacher incentives are } \\
\text { also important. }\end{array}$ & $\begin{array}{l}\text { Not } \\
\text { considered }\end{array}$ & $\begin{array}{l}\text { Mostly } \\
\text { insignificant, } \\
\text { but if } \\
\text { significant } \\
\text { then positive } \\
\text { for transition } \\
\text { countries }\end{array}$ & $\begin{array}{l}\text { Not } \\
\text { considered }\end{array}$ \\
\hline $\begin{array}{l}39 \\
\text { countries } \\
\text { including } 8 \\
\text { transition } \\
\text { ones }\end{array}$ & $\begin{array}{l}\text { Woessmann } \\
(2003)\end{array}$ & $\begin{array}{l}\text { Clustering- } \\
\text { robust linear } \\
\text { regression }\end{array}$ & $\begin{array}{l}\text { TIMSS } \\
\text { scores }\end{array}$ & $\begin{array}{l}\text { Institutions (external } \\
\text { testing, school and } \\
\text { teacher autonomy, } \\
\text { school competition) } \\
\text { matter, as well as } \\
\text { individual and family }\end{array}$ & $\begin{array}{l}\text { Not } \\
\text { considered }\end{array}$ & $\begin{array}{l}\text { Positive } \\
\text { significant } \\
\text { but quite } \\
\text { small }\end{array}$ & Insignificant \\
\hline
\end{tabular}




\begin{tabular}{|c|c|c|c|c|c|c|c|}
\hline & & & & $\begin{array}{l}\text { characteristics, while } \\
\text { school resources } \\
\text { don't. }\end{array}$ & & & \\
\hline Latvia & Hazans (2010) & $\begin{array}{l}\text { Linear mixed } \\
\text { models for } \\
\text { panel data }\end{array}$ & $\begin{array}{l}\text { Share of } \\
\text { municipal } \\
\text { and state } \\
\text { funding in } \\
\text { wage bill } \\
\text { Teacher } \\
\text { earnings }\end{array}$ & $\begin{array}{l}\text { Ratio of preschool } \\
\text { students to school } \\
\text { students positive } \\
\text { School is a state } \\
\text { gymnasium positive } \\
\text { Rural school negative }\end{array}$ & Negative & Positive & Positive \\
\hline Bulgaria & $\begin{array}{l}\text { World Bank } \\
\text { report } 2010\end{array}$ & $\begin{array}{l}\text { OLS and } \\
\text { difference in } \\
\text { difference } \\
\text { OLS }\end{array}$ & $\begin{array}{l}\text { School } \\
\text { dropout rate } \\
\text { PISA Math } \\
\text { achievement } \\
\text { result }\end{array}$ & $\begin{array}{l}\text { School closure } \\
\text { positive } \\
\\
\text { Linguistic minority } \\
\text { and poorest } \\
\text { negative }\end{array}$ & $\begin{array}{l}\text { Negative } \\
\text { However, } \\
\text { small schools } \\
\text { favour } \\
\text { linguistic } \\
\text { minorities and } \\
\text { the poorest }\end{array}$ & $\begin{array}{l}\text { Not } \\
\text { considered }\end{array}$ & $\begin{array}{l}\text { Not } \\
\text { considered }\end{array}$ \\
\hline China & $\begin{array}{l}\text { Liu et al } \\
(2009)\end{array}$ & $\begin{array}{l}\text { Difference in } \\
\text { difference } \\
\text { OLS, } \\
\text { propensity } \\
\text { score } \\
\text { matching }\end{array}$ & $\begin{array}{lr}\text { Z-scores } & \text { in } \\
\text { Chinese and } \\
\text { Math and } \\
\text { change in } \\
\text { scores after } \\
\text { school } \\
\text { merger }\end{array}$ & $\begin{array}{l}\text { School merger } \\
\text { benefits older students } \\
\text { (after } 4^{\text {th }} \text { grade) but } \\
\text { not younger ones }\end{array}$ & $\begin{array}{l}\text { Not } \\
\text { considered }\end{array}$ & Negative & $\begin{array}{l}\text { Negative, } \\
\text { but } \\
\text { significant } \\
\text { only for } \\
\text { Math scores }\end{array}$ \\
\hline Czech & Filer & Tobit & Private/public & Increases with wage, & Not & Negative for & Not \\
\hline
\end{tabular}




\begin{tabular}{|c|c|c|c|c|c|c|c|}
\hline $\begin{array}{l}\text { Republic } \\
\text { compared } \\
\text { to other } \\
\mathrm{CEE} \text { and } \\
\mathrm{EU} \\
\text { countries }\end{array}$ & Munich (2002) & OLS & $\begin{array}{l}\text { schools } \\
\text { enrollment } \\
\text { Graduation } \\
\text { exams scores }\end{array}$ & $\begin{array}{lr}\text { unemployment } & \text { and } \\
\text { business } & \text { sector } \\
\text { development } & \end{array}$ & considered & exam scores & considered \\
\hline Poland & $\begin{array}{l}\text { Herczynski } \\
\text { and Herbst } \\
(2005)\end{array}$ & OLS & $\begin{array}{l}\text { Log of } \\
\text { average math } \\
\text { and science } \\
\text { test score } \\
\text { Interschool } \\
\text { standard } \\
\text { deviation of } \\
\text { score }\end{array}$ & $\begin{array}{l}\text { School concentration } \\
\text { (H index) has } \\
\text { negative impact. } \\
\text { Number of schools } \\
\text { has positive effect but } \\
\text { it diminishes after } 4^{\text {th }} \\
\text { school is added. } \\
\text { Only H index is } \\
\text { significant (negative), } \\
\text { number of schools has } \\
\text { positive and } \\
\text { increasing effect. }\end{array}$ & $\begin{array}{l}\text { Not } \\
\text { considered }\end{array}$ & $\begin{array}{l}\text { Marginally } \\
\text { significant } \\
\text { (positive) } \\
\text { but very } \\
\text { small }\end{array}$ & $\begin{array}{l}\text { Not } \\
\text { considered }\end{array}$ \\
\hline Poland & $\begin{array}{l}\text { Bukowska and } \\
\text { Siwińska- } \\
\text { Gorzelak } \\
\text { (2011) }\end{array}$ & $\begin{array}{l}\text { OLS, data } \\
\text { envelopment } \\
\text { analysis }\end{array}$ & $\begin{array}{l}\text { A national } \\
\text { school test } \\
\text { score }\end{array}$ & $\begin{array}{l}\mathrm{H} \text { index - negative, } \\
\text { PIT income positive, } \\
\text { social and transport } \\
\text { expenditures, and } \\
\text { population - negative. }\end{array}$ & Positive & $\begin{array}{l}\text { Not } \\
\text { considered }\end{array}$ & $\begin{array}{l}\text { Not } \\
\text { considered }\end{array}$ \\
\hline Poland & $\begin{array}{l}\text { Jakubovskyand } \\
\text { Sakowski } \\
(2006) .\end{array}$ & $\begin{array}{l}\text { OLS, 2SLS, } \\
\text { IV }\end{array}$ & $\begin{array}{l}\text { Class mean } \\
\text { score for } 6^{\text {th }} \\
\text { grade exam }\end{array}$ & $\begin{array}{l}\text { Increasing rural } \\
\text { schools classes to } \\
\text { equal those of urban }\end{array}$ & $\begin{array}{l}\text { Positive } \\
\text { significant but } \\
\text { very small }\end{array}$ & $\begin{array}{l}\text { Positive } \\
\text { significant, } \\
\text { but becomes }\end{array}$ & $\begin{array}{l}\text { Not } \\
\text { considered }\end{array}$ \\
\hline
\end{tabular}




\begin{tabular}{|c|c|c|c|c|c|c|c|}
\hline & & & & $\begin{array}{l}\text { schools will widen } \\
\text { exam-scores gap } \\
\text { between them, } \\
\text { contrary to the policy- } \\
\text { makers belief. }\end{array}$ & & $\begin{array}{l}\text { negative } \\
\text { when } \\
\text { controlled } \\
\text { for total } \\
\text { school } \\
\text { enrollment }\end{array}$ & \\
\hline Hungary & $\begin{array}{l}\text { Hermann } \\
(2005)\end{array}$ & $\begin{array}{l}\text { Multinomial } \\
\text { logit }\end{array}$ & $\begin{array}{l}\text { Share of } \\
\text { primary } \\
\text { school } \\
\text { students } \\
\text { continuing } \\
\text { studies in } \\
\text { academic, } \\
\text { vocational } \\
\text { secondary or } \\
\text { vocational } \\
\text { training } \\
\text { schools }\end{array}$ & $\begin{array}{l}\text { Living in a larger city } \\
\text { and with more } \\
\text { educated parents } \\
\text { increases probability } \\
\text { of higher education. }\end{array}$ & $\begin{array}{l}\text { Negatively } \\
\text { significant }\end{array}$ & Insignificant & Insignificant \\
\hline Hungary & $\begin{array}{l}\text { Hermann } \\
(2004 b)\end{array}$ & $\begin{array}{l}\text { Fixed effects } \\
\text { logit }\end{array}$ & $\begin{array}{l}\text { Choice of } \\
\text { either general } \\
\text { or vocational } \\
\text { secondary } \\
\text { school or a } \\
\text { technical } \\
\text { school after } \\
8^{\text {th grade }} \\
\text { (primary }\end{array}$ & $\begin{array}{l}\text { Share of students in } \\
\text { child-care after } \\
\text { lessons and share of } \\
\text { students with special } \\
\text { needs positively } \\
\text { influence choice of } \\
\text { better schools }\end{array}$ & $\begin{array}{l}\text { Negative } \\
\text { impact on } \\
\text { probability of } \\
\text { better } \\
\text { secondary } \\
\text { school choice }\end{array}$ & $\begin{array}{l}\text { Not } \\
\text { considered }\end{array}$ & $\begin{array}{l}\text { Not } \\
\text { considered }\end{array}$ \\
\hline
\end{tabular}




\begin{tabular}{|c|c|c|c|c|c|c|c|}
\hline & & & school) & & & & \\
\hline Romania & $\begin{array}{l}\text { Kallai and } \\
\text { Maniu (2004) }\end{array}$ & $\begin{array}{l}\text { Random } \\
\text { effects for } \\
\text { panel data }\end{array}$ & $\begin{array}{l}\text { National } \\
\text { exam test } \\
\text { score, school } \\
\text { averages }\end{array}$ & $\begin{array}{l}\text { Share of qualified } \\
\text { teachers positive. }\end{array}$ & $\begin{array}{l}\text { Positive both } \\
\text { for city (avg. } \\
500 \text { students) } \\
\text { and rural/town } \\
\text { schools (avg. } \\
150 \text { students) }\end{array}$ & Insignificant & $\begin{array}{l}\text { Negative for } \\
\text { urban } \\
\text { schools }\end{array}$ \\
\hline Romania & Porta (2011) & $\begin{array}{l}\text { Panel data, } \\
\text { correlation } \\
\text { analysis }\end{array}$ & PiSA scores & $\begin{array}{l}\text { Correlation of schools } \\
\text { size and scores is } \\
\text { small but negative. }\end{array}$ & $\begin{array}{l}\text { After } \\
\text { controlling for } \\
\text { family } \\
\text { background, } \\
\text { school size } \\
\text { effect is } \\
\text { significant } \\
\text { only for } \\
\text { reading. }\end{array}$ & $\begin{array}{l}\text { Not } \\
\text { considered }\end{array}$ & $\begin{array}{l}\text { Not } \\
\text { considered }\end{array}$ \\
\hline Serbia & $\begin{array}{l}\text { McDonald et } \\
\text { al (2009) }\end{array}$ & $\begin{array}{l}\text { Panel data, } \\
\text { correlation } \\
\text { analysis }\end{array}$ & PiSA scores & $\begin{array}{l}\text { Mean scores for small } \\
\text { schools are lower and } \\
\text { significant for all } \\
\text { subjects }\end{array}$ & $\begin{array}{l}\text { Controlling } \\
\text { for student } \\
\text { and family } \\
\text { characteristics, } \\
\text { small schools } \\
\text { have negative } \\
\text { significant } \\
\text { effect on } \\
\text { scores. }\end{array}$ & $\begin{array}{l}\text { Not } \\
\text { considered }\end{array}$ & $\begin{array}{l}\text { Not } \\
\text { considered }\end{array}$ \\
\hline
\end{tabular}


